\title{
Acid Resistance, Water Permeability and Chloride Penetrability of Concrete Containing Crushed Basalt as
}

\section{Aggregates}

\author{
Aref M. al-Swaidani ${ }^{1 *}$, Mohammad K. Baddoura ${ }^{2}$, Samira D. Aliyan ${ }^{3}$ and Walid Choeb ${ }^{4}$ \\ 1. Assistant professor \& Vice-Dean, Faculty of Architectural Engineering, Arab International University (AIU), Damascus, Syria \\ 2. Professor, Head of Syrian Code Committee, the Order of Syrian Engineers, Damascus, Syria \\ 3. Researcher, Syrian Arab Organization for standardization and Metrology (SASMO), Damascus, Syria \\ 4. Researcher \& Consultant, the Order of Syrian Engineers, As-Swaida'a, Syria
}

\begin{abstract}
Basaltic rocks are used extensively as engineering materials including aggregates for Portland cement concrete and asphalt concrete. Syria is very rich in Basaltic rocks. There are reserves estimated to be several billion tonnes according to recent geological investigations. The annual production of concrete in Syria is about 20 million $\mathrm{m}^{3}$, containing about 35 million tonnes of aggregates. Due to some concerns, use of basalt as concrete aggregate is very limited in Syria. Because of additional costs of transportation of dolomite aggregate produced in quarries located about $200 \mathrm{~km}$ far from the southern region, studying suitability of basaltic rocks occurring in As-Swaida'a region as local aggregate source would be very important. As-Swaida is basically an agricultural city. However, it has recently witnessed urban and industrial developments. This paper is part of larger research on evaluating the basaltic rocks extracted from As-Swaida'a region, as a potential source of concrete aggregate. Effects of aggressive acidic environments on concrete have been investigated through 3 months of exposure to $5 \% \mathrm{H}_{2} \mathrm{SO}_{4}, 10 \% \mathrm{HCl}, 5 \% \mathrm{HNO}_{3}$ and $10 \% \mathrm{CH}_{3} \mathrm{COOH}$ solutions. In addition, concrete permeability measured in terms of water penetration depth was evaluated for concrete after two curing time of 28 and 90 days. A RCPT (Rapid chloride penetration test) has also been carried out according to ASTM C 1202. Dolomite aggregate were used for comparison. Petrographical, chemical and physical characteristics of basaltic rocks have been reported as well. The experimental results revealed that As-Swaida'a basaltic rocks were suitable for production of crushed rock aggregates for concrete production. The resistance to all acidic solutions, except $\mathrm{H}_{2} \mathrm{SO}_{4}$ solution, was improved substantially with the use of basalt aggregate. In addition, the resistance to water permeation and to chloride penetration of concrete increased with the use of basalt aggregates compared with dolomite aggregate. Moreover, definite correlations were noted between some acidic attacks.
\end{abstract}

Key words: Acid resistance, aggregate, basalt, chloride penetration, durability, water permeability.

\section{Introduction}

Basalt is the most common type of extrusive igneous rock and the most common rock type at the earth surface [1]. Basaltic rocks are used extensively as engineering materials including aggregates for Portland cement concrete and asphaltic concrete [2]. Few published test results on the properties of basaltic rock aggregates indicate that the use of crushed basalt

*Corresponding author: Aref M. al-Swaidani, assistant professor \& vice-dean of faculty of architectural engineering, Arab International University, research field: durability of reinforced concrete structures. E-mail: aydlswaidani@yahoo.fr; a-swaidani@aiu.edu.sy. aggregate can significantly affect the properties of concrete [3-5]. Use of basalts as aggregate material is very limited in Syria. For this reason, a particular attention was recently given to the exploitation of basalt which is broadly abundant in Syria. More than $30,000 \mathrm{~km}^{2}$ of the country is covered by Teritary and Quaternary-age volcanic rocks [6], among which basalt occupies important volume with estimated reserves of about several billion tonnes [7]. There are few geological investigations on these volcanic rocks. However, their potential used as concrete aggregate is still not well established. 
Volcanic rocks are widespread in As-Swaida'a region of Syria [6]. As-Swaida'a is basically an agricultural city. It is a mountainous region covered with about 3 and 5 million trees of apple and grapevine respectively. It is famous for producing juice, drinks and vinegar which is usually a $5 \%$ solution of acetic acid [8]. Recently, As-Swaida'a has witnessed urban and industrial developments. The premature deterioration of concrete structures due to aggressive environments represents an increasing problem in Syria. It became more obvious, especially, in the agricultural and industrial environments. So, owing to the spread of damages of concrete structures in these agricultural and industrial areas, this topic represents an increasing significance.

Concrete is highly alkaline with $\mathrm{pH}$ values normally above 12.5 , and is easily attacked by acid solutions [9]. Aggregate type affects the performance of concrete against acid attack. Limestone and dolomite aggregates are more vulnerable to acid attacks [10-12]. Use of such aggregates in concrete sewers may prolong life by spreading the acid attack between aggregate and cement paste [12]. Siliceous aggregates are generally acid resistant [10-12]. However, these may be susceptible to attack by alkalis, depending on the nature of the silica minerals [12]. The spectrum of aggressive acidic media is broad. Some of the most common acids which attack concrete and their likely occurrence are summarized in Table 1.

Permeability of concrete to water is closely related to the durability of concrete. Permeability is the rate at which aggressive agents penetrate through concrete. Water penetration depth can be considered as an indication of permeable and impermeable concrete [10]. In addition, chloride penetrability of concrete is one of the major problems that affect the durability of RC (Reinforced concrete) structures. Although chloride ions in concrete do not directly cause severe damage to the concrete, they contribute to the corrosion of embedded steel bars in the reinforced concrete. Therefore, the study of this aspect is important for evaluating corrosion of reinforcing steel in RC structures.

Although there are a lot of studies on using basalt rocks as concrete aggregate, no detailed research was conducted in the past to investigate the potential use of basalt as concrete aggregate in Syria. This study is part of the first detailed research in Syria to investigate the potential utilization of basalt as concrete aggregate, and to study the effects of their use on the performance of concrete. The study is particularly important not only for the country but also for other areas of similar geology, e.g. Harrat Al-Shaam, a volcanic field covering a total area of $45,000 \mathrm{~km}^{2}$, third of which is located in the country (Fig. 1). The rest is covering parts from Jordan and Saudia Arabia. The objective of

Table 1 Some of common acids, solubility of calcium salts, chemical formula and their likely occurrence.

\begin{tabular}{|l|l|l|}
\hline Chemical substance & Formula & Likely occurrence \\
\hline $\begin{array}{l}\text { Sulfuric acid } \\
\text { (Solubility of calcium } \\
\text { sulfate in water: } 0.20 \%)\end{array}$ & $\mathrm{H}_{2} \mathrm{SO}_{4}$ & $\begin{array}{l}\text { Natural ground waters [13, 14], chemical industry [13], effluents from furnaces (that use } \\
\text { high-sulfur fuels) [15, 16], some industrial waste-waters [14, 15], decay of organic matter in } \\
\text { sewer pipes(sewage system) often leads to the formation of } \mathrm{H}_{2} \mathrm{~S} \text { gas which is transformed } \\
\text { into sulfuric acid by bacterial action [13-17], oil refinery [18], textile manufacturing [18], } \\
\text { acid rain [11, 14, 19], some mineral waters [17], explosives, wood pulp mills or from } \\
\text { fertilizer manufacture [16] }\end{array}$ \\
\hline $\begin{array}{l}\text { Hydrochloric acid } \\
\text { (Solubility of calcium } \\
\text { chloride in water: } 46.08 \%)\end{array}$ & $\mathrm{HCl}$ & $\begin{array}{l}\text { Chemical industry [20], textile manufacturing [18], oil refinery [18], food processing plants } \\
\text { [18], through pickling and cleaning of metals [16] or from combustion of carbon, paper and } \\
\text { organic plastic materials [21] }\end{array}$ \\
\hline $\begin{array}{l}\text { Nitric acid } \\
\text { (Solubility of calcium } \\
\text { nitrate in water: } 56.00 \%)\end{array}$ & $\mathrm{HNO}_{3}$ & $\begin{array}{l}\text { Chemical industry [22], fertilizer manufacture [19, 20], produced by microorganisms, } \\
\text { namely bacteria, as end-products of their metabolisms [23], nitrifying basins of waste water } \\
\text { treatment plants [24] and acid rain [11, 16]. }\end{array}$ \\
\hline $\begin{array}{l}\text { Acetic acid } \\
\text { (Solubility of calcium } \\
\text { acetate in water: } 52.00 \%)\end{array}$ & $\mathrm{CH}_{3} \mathrm{COOH}$ & $\begin{array}{l}\text { Effluents from agricultural and agrofood industries such as breeding, dairy or sugar } \\
\text { industries [17, 25], fermentation processes [20], cider vinegar, sour alcoholic beverages } \\
\text { [16], paper mills [26], farm silage [16, 17], acetate plastics (vinyl, cellulose, ..), } \\
\text { photographic chemicals, rubber latex, insecticides, on garbage feeding floors for animals } \\
\text { [26] or in manure [16] }\end{array}$ \\
\hline
\end{tabular}




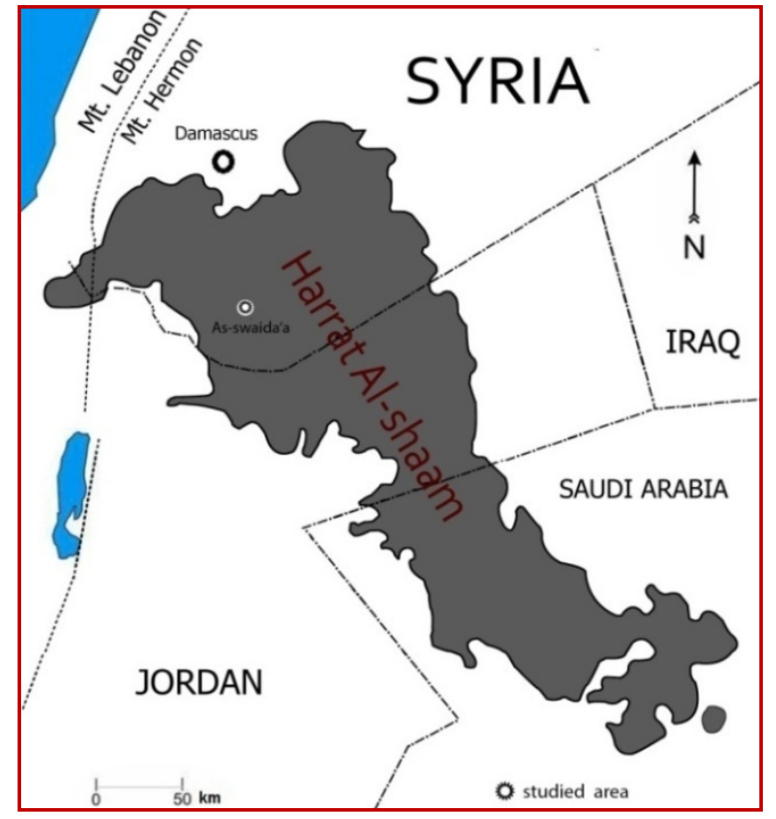

(a)

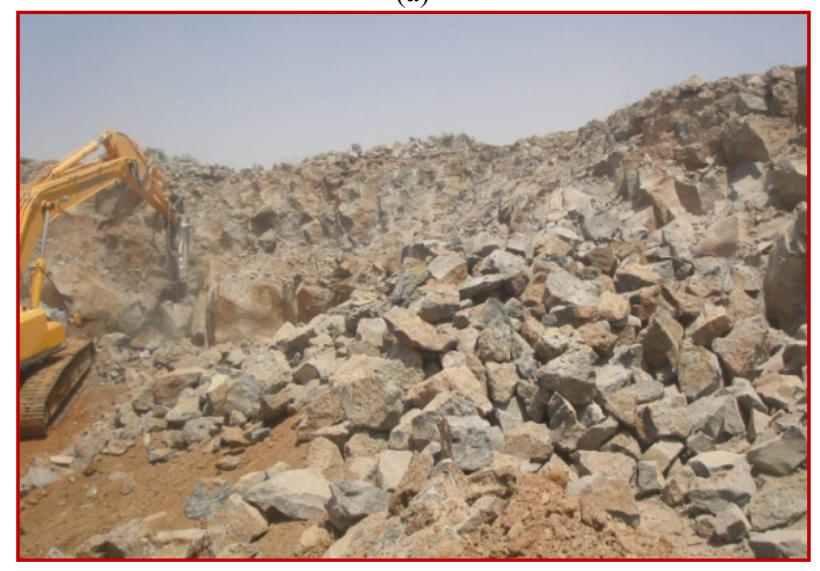

(b)

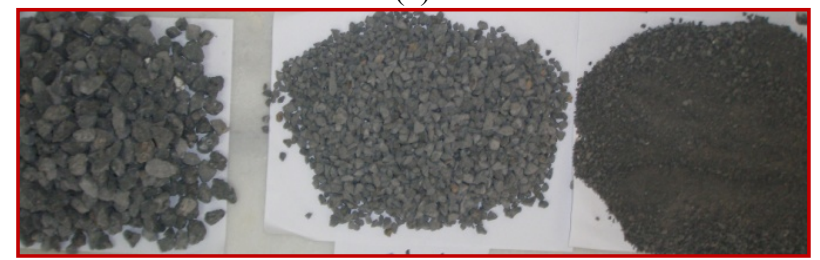

(c)

Fig. 1 (a) Map of Harrat Al-Shaam, (b) photo of the studied quarry and (c) the used basalt aggregate.

this paper is to report a part of this ongoing research on the effect of crushed basalt aggregates on some durability-related properties. Acid resistance, water permeability and chloride penetrability have been particularly investigated. Some petrographical, chemical, physical and mechanical properties also have been reported.

\section{Experimental}

\subsection{Materials}

\subsubsection{Basalt}

The basalt used in the experiments was collected from As-Swaida region, about $100 \mathrm{~km}$ southeast of Damascus, as shown in the Fig. 1. The petrographical examination showed that olivine, clinopyroxene, plagioclase and volcanic glass were the main constituents of basalt. Their percentages were approximately $18 \%, 21 \%, 32 \%$ and $20 \%$, respectively. Traces of clay minerals were also observed. Fig. 2 shows thin sections of the used basalt. Crushed dolomite extracted from Hassia region, about $120 \mathrm{~km}$ north of Damascus, was also used for comparison. The chemical analysis of 6 basalt samples collected from different sites in Swaida, is summarized in Table 2 and Fig. 3 respectively. The chemical analysis of the dolomite used in the study is also listed in Table 2. This analysis was carried out by means of X-Ray fluorescence.

\subsubsection{Cement Samples}

The cement used in the experiments was obtained from Adra Cement Plant, Damascus, Syria. Chemical analysis of cement is shown in Table 2.

\subsubsection{Concrete Mixes}

Two concrete mixes were prepared. The first mix was prepared by using crushed basalt aggregate while the other by crushed dolomite aggregate. The grading of aggregate mixtures was kept nearly close to fuller's curve for both concrete mixes. Chemical composition, some physical properties and grading of the aggregates are illustrated in Table 2, Table 3 and Figs. 4-6 respectively. Their quantities in $1 \mathrm{~m}^{3}$ concrete mix based on oven-dry condition are summarized in Table 4. All concrete mixes were designed to have a water-binder ratio of 0.6 which is a commonly used ratio in the local concrete plants, and a slump of $100 \pm$ $20 \mathrm{~mm}$. Nine concrete cubes $(150 \mathrm{~mm})$ were cast for each of aggregate type and curing age for the determination of compressive strength and three for the 


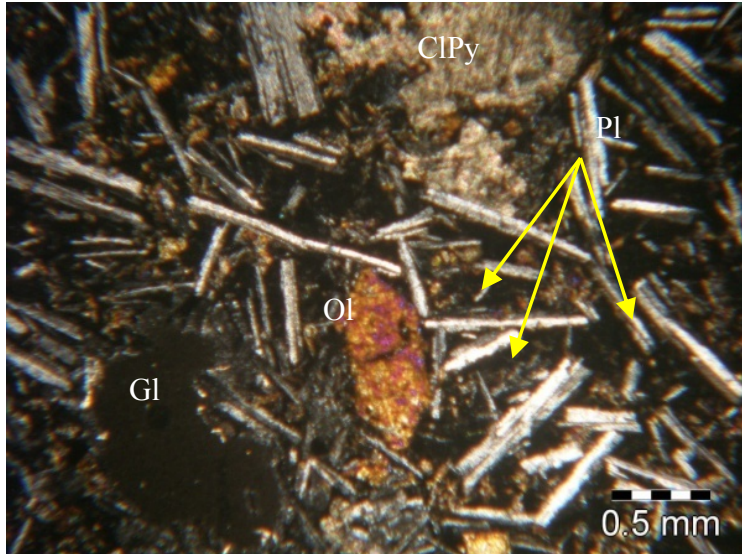

(a)

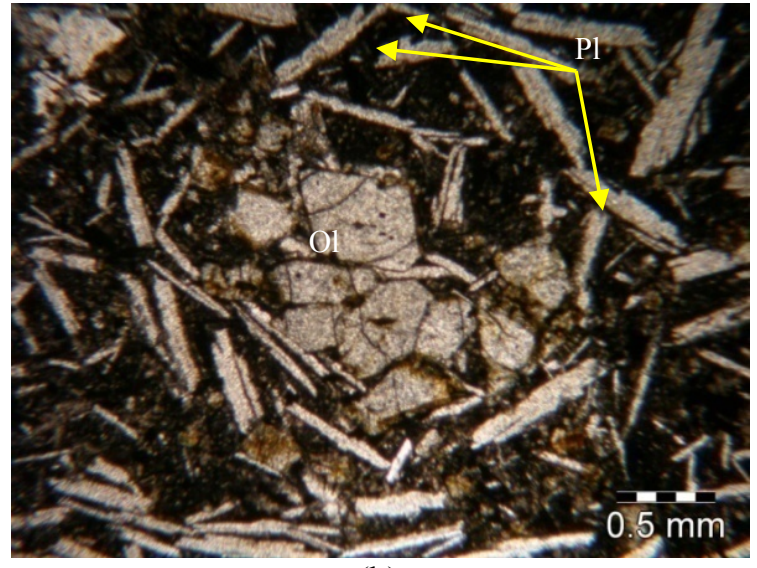

(b)

Fig. 2 Thin sections of the basalt. (a) Microphenocryst of Olivine, Clinopyrosene and elongated plagioclase in volcanic glass matrix; (b) Microphenocrysts of Olivine and elongated plagioclase in volcanic glass matrix (Gl: Volcanic glass, Ol: Olivine, ClPy: Clinopyroxene, Pl: Plagioclase).

Table 2 Chemical composition of the used materials.

\begin{tabular}{lllll}
\hline $\begin{array}{l}\text { Chemical composition } \\
\text { (by mass, \%) }\end{array}$ & \multicolumn{4}{c}{ Materials } \\
\cline { 2 - 5 } $\mathrm{SiO}_{2}$ & Basalt & The used crushed basalt & Dolomite & Cement \\
$\mathrm{Al}_{2} \mathrm{O}_{3}$ & $43.80-46.95$ & 45.76 & 0.42 & 20.43 \\
$\mathrm{Fe}_{2} \mathrm{O}_{3}$ & $15.18-18.22$ & 16.87 & 0.38 & 5.86 \\
$\mathrm{CaO}$ & $12.60-15.70$ & 14.39 & 0.10 & 3.20 \\
$\mathrm{MgO}$ & $7.93-9.70$ & 8.93 & 31.40 & 61.69 \\
$\mathrm{Na}_{2} \mathrm{O}$ & $4.14-7.79$ & 6.61 & 20.46 & 2.31 \\
$\mathrm{~K}_{2} \mathrm{O}$ & $1.72-2.97$ & 2.64 & 0.06 & 0.81 \\
$\mathrm{TiO}_{2}$ & $0.46-1.13$ & 1.05 & 0.30 & 0.24 \\
$\mathrm{Mn}_{2} \mathrm{O}_{3}$ & $2.14-3.04$ & 2.53 & 0.18 & 0.25 \\
$\mathrm{Cl}^{-}$ & $0.13-0.18$ & 0.16 & - & - \\
$\mathrm{SO}_{3}$ & $0-0.02$ & 0.01 & 0.021 & 0.05 \\
$\mathrm{Loss}$ on ignition & - & - & - & 2.30 \\
Insoluble residue & $1.10-1.30$ & 1.10 & 46.48 & 2.29 \\
$\mathrm{C} 3 \mathrm{~S}$ & - & - & - & 0.59 \\
$\mathrm{C} 2 \mathrm{~S}$ & & & & 45.30 \\
$\mathrm{C} 3 \mathrm{~A}$ & & & & 24.48 \\
$\mathrm{C} 4 \mathrm{AF}$ & & & & 10.12 \\
\hline
\end{tabular}

determination of water penetration depth. A total of 102 concrete cubes $(150 \mathrm{~mm})$ were cast. Three concrete cylinders $(100 \mathrm{~mm} \times 200 \mathrm{~mm})$ for each of aggregate type, curing age and solution type were cast, for investigating the acid resistance of concrete mixes and for evaluating the penetrability of chloride ions. A total of 48 concrete cylinders $\left(100 \times 200 \mathrm{~mm}^{2}\right)$ were cast. Two slices of $100 \mathrm{~mm}$ in diameter and 50 $\mathrm{mm}$ in thickness were cut from the middle portion of each concrete cylinder specimens $\left(100 \times 200 \mathrm{~mm}^{2}\right)$. One was used for immersion in the acid solution, while the other was used for chloride penetrability test.

All concrete specimens were cast in three layers and compacted using a vibrating table. After casting, the moulded specimens were covered and left in the casting room for $24 \mathrm{~h}$. They were then demoulded and immersed in $21 \pm 2{ }^{\circ} \mathrm{C}$ lime-saturated water until the test age. 


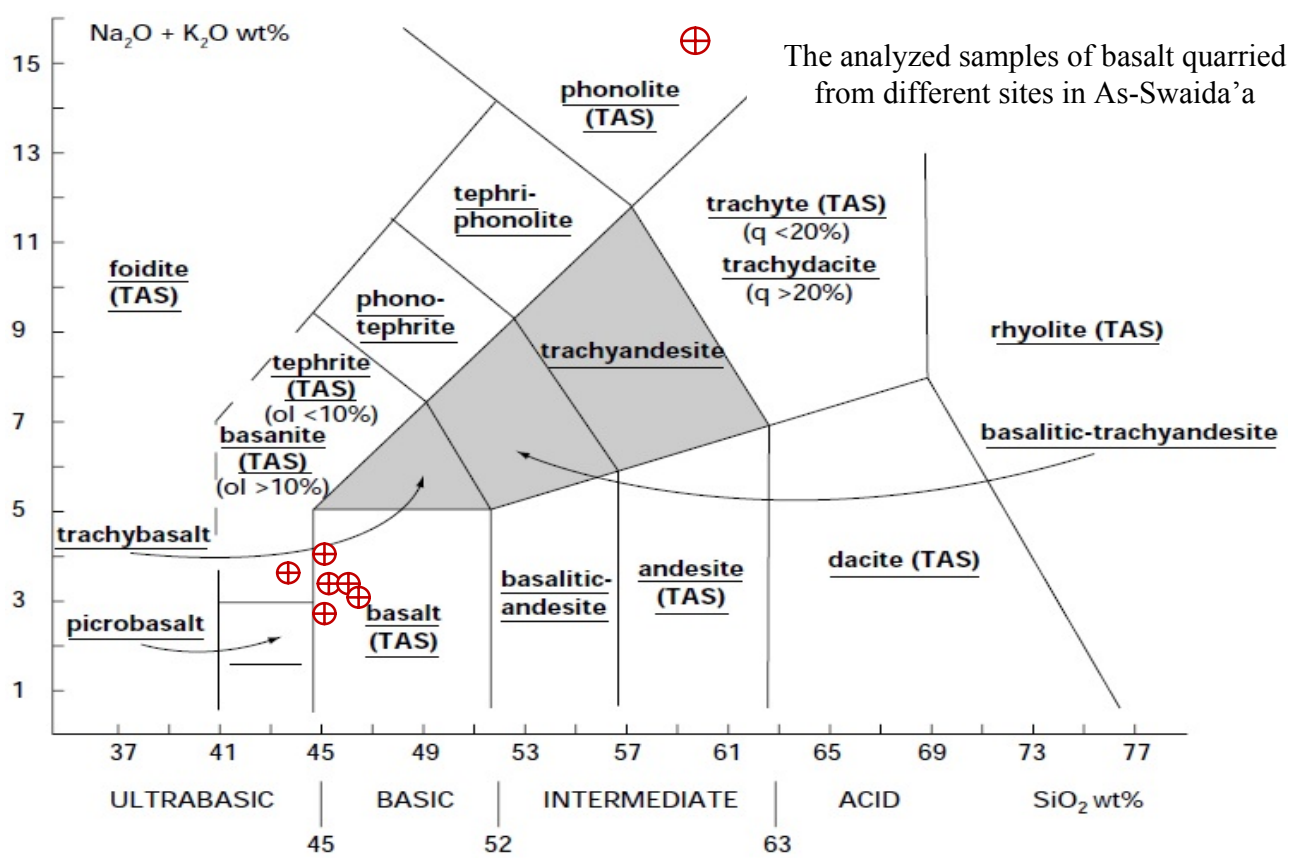

Fig. 3 Classification of the basalt samples quarried from As-Swaida according to Le Maitre et al. [27].

Table 3 Comparison of some characteristics of crushed basalt and dolomite with some typical acceptance limits.

\begin{tabular}{|c|c|c|c|c|c|c|c|}
\hline \multirow[t]{2}{*}{ Characteristic } & \multicolumn{3}{|c|}{$\begin{array}{l}\text { Crushed basalt } \\
\text { aggregates }\end{array}$} & \multicolumn{3}{|c|}{ Crushed dolomite aggregates } & \multirow[t]{2}{*}{ Acceptance limits } \\
\hline & Fine & Medium-size & coarse & Fine & Medium- size & coarse & \\
\hline Specific Gravity & 2.72 & 2.78 & 2.78 & 2.70 & 2.71 & 2.71 & $>2.6[\mathrm{BS} \mathrm{812:1975]}$ \\
\hline Absorption (\%) & 1.56 & 1.33 & 1.33 & 1.50 & 1.45 & 1.45 & $\begin{array}{l}<2 \text { [ASTM C 33:1986] } \\
<2.5[\text { ASTM C127] } \\
<3[\text { BS 8007:1987] }\end{array}$ \\
\hline $\begin{array}{l}\text { Sand Equivalent (\%) [ASTM } \\
\text { D2419] }\end{array}$ & 87 & & & 75 & & & $>70 \%[28]$ \\
\hline Los Angeles (\%) & & & 17.03 & & & 22.15 & $\begin{array}{l}<45 \text { (500 cycles) [ASTM C } \\
33: 1986] \\
<25 \% \text { for wearing surfaces } \\
\text { [ASTM } C 131 \text { ] }\end{array}$ \\
\hline $\begin{array}{l}\mathrm{Na}_{2} \mathrm{SO}_{4} \text { Soundness (\%) (ASTM } \\
\mathrm{C} 88 \text { ) }\end{array}$ & & & 0.394 & & & 0.464 & $\begin{array}{l}<12 \text { (coarse aggregate) after } \\
5 \text { cycles in } \mathrm{Na}_{2} \mathrm{SO}_{4} \\
\text { [ASTM C 33; ASTM C88] }\end{array}$ \\
\hline $\begin{array}{l}\text { Assessment of alkali-silica reaction } \\
\text {; Expansion (\%) at } 14 \text { days }\end{array}$ & 0.02 & & & & & & $\begin{array}{l}<0.1 \text { at } 14 \text { days } \\
{[\text { ASTM C } 1260: 1994]}\end{array}$ \\
\hline $\begin{array}{l}\text { Thermal conductivity }(\mathrm{W} / \mathrm{m} . \mathrm{k}) \\
\text { (rock sample: } 150 \times 150 \times 50 \mathrm{~mm})\end{array}$ & 1.81 & & & 2.64 & & & \\
\hline Particle finer than $75 \mu \mathrm{m}(\%)$ & 3.50 & & & 6.47 & & & $<5 \%$ [ASTM C 33] \\
\hline Chloride content $\left(\mathrm{Cl}^{-}\right)$ & & & 0.01 & & & 021 & $<0.05 \%$ [BS 882:1992], [17] \\
\hline Sulfate content $\left(\mathrm{SO}_{3}\right)$ - - & & & & & & & $\begin{array}{l}<0.2 \%[29] \\
<0.4 \%[12],[\text { BS } 812: 118]\end{array}$ \\
\hline
\end{tabular}

\subsection{Methods}

\subsubsection{Compressive Strength Test of Concrete}

The compressive strength development was determined on $150 \mathrm{~mm}$ cubic concrete specimens, according to ISO 4012, at ages of 2, 3, 7, 28 and 90 days.

\subsubsection{Acid Resistance}

The relative acid resistance was determined in accordance with ASTM C-267 (standard test method 


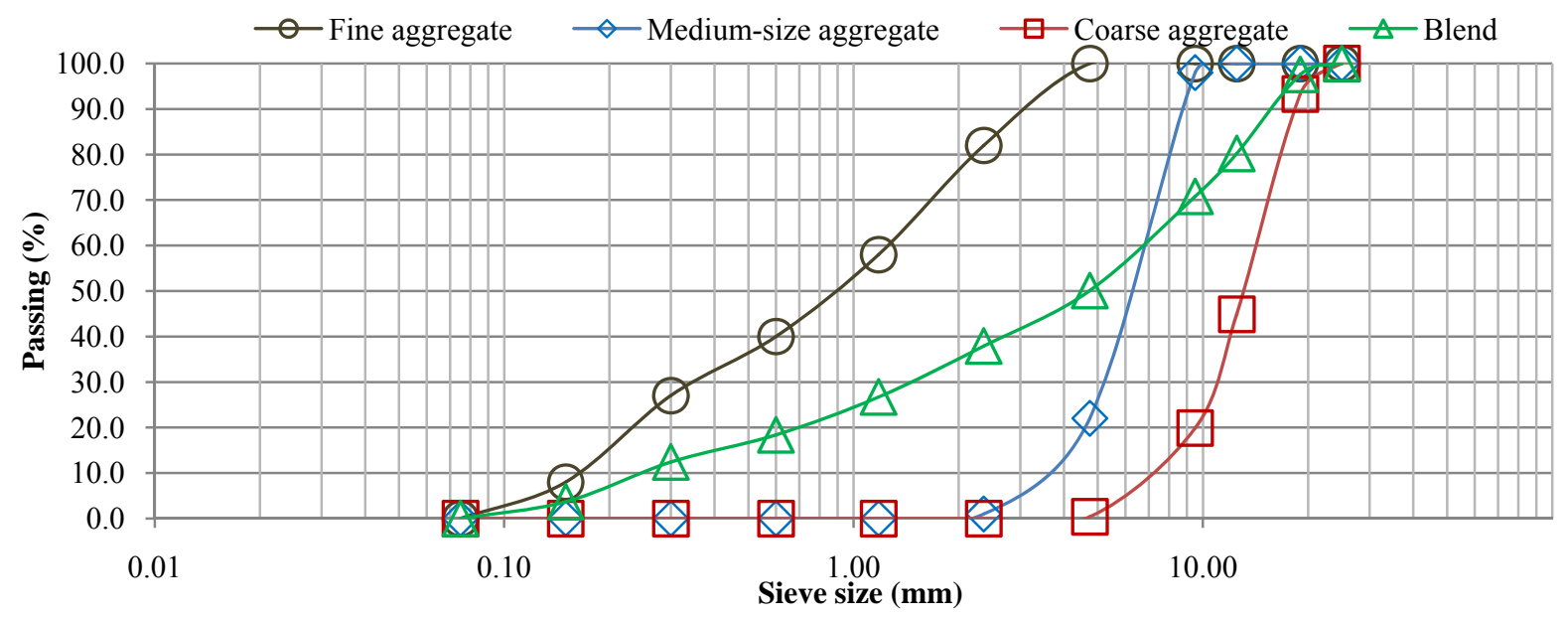

Fig. 4 Grading curve of basalt aggregates used in the concrete mixes.

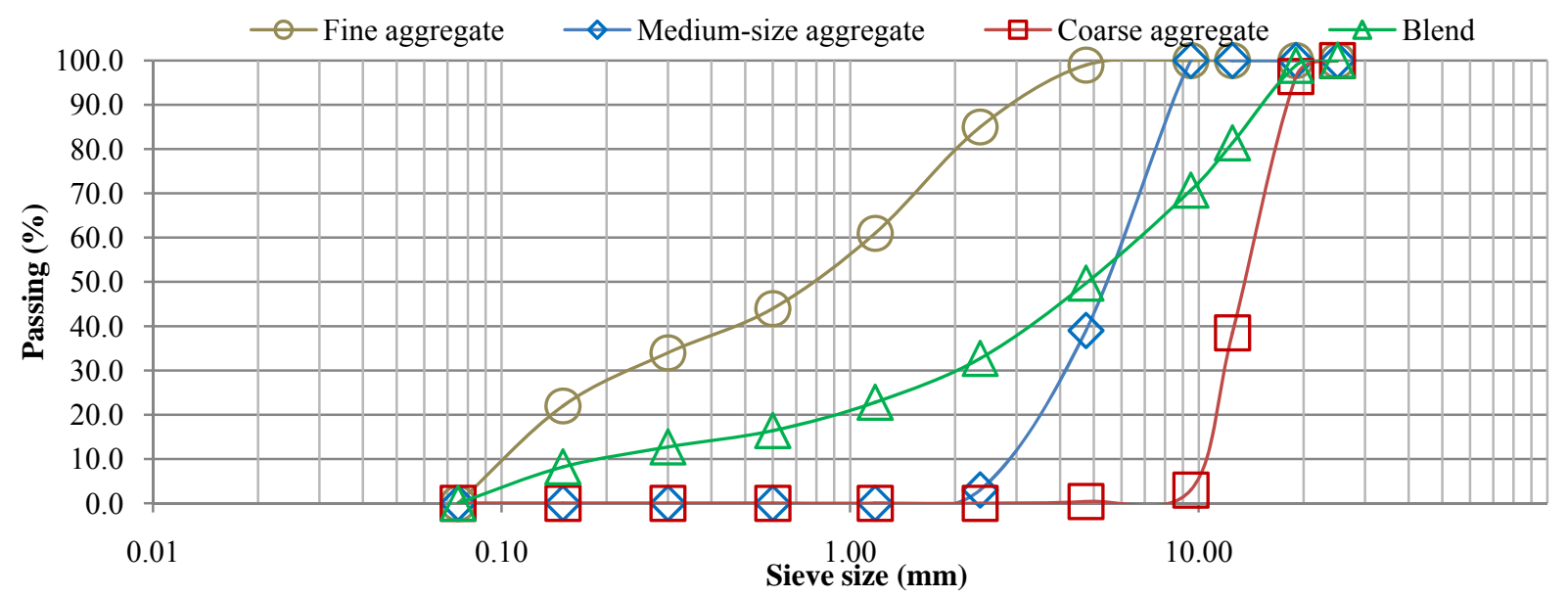

Fig. 5 Grading curve of dolomite aggregates used in the concrete mixes.

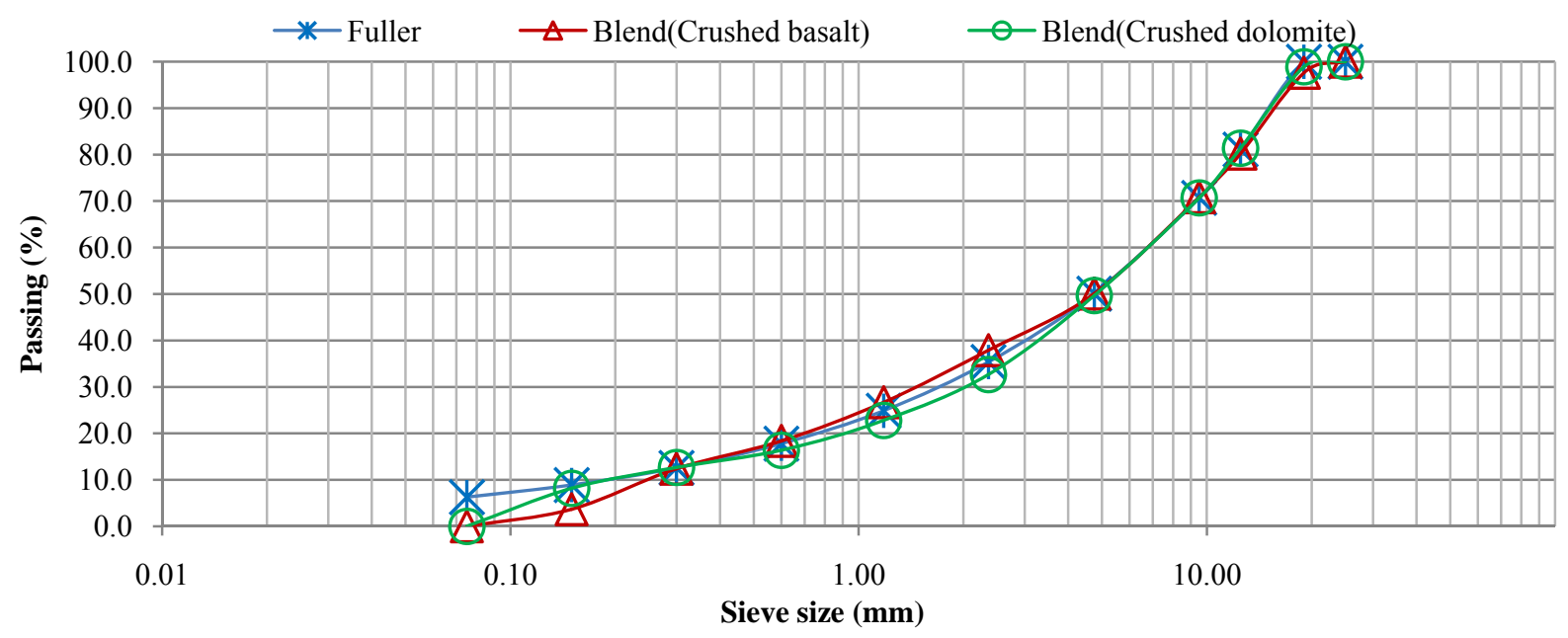

Fig. 6 Grading curve of basalt \& dolomite aggregate blends used in the concrete mixes with fuller's curve. 
Table 4 Ingredients of the concrete mixes.

\begin{tabular}{|c|c|c|c|c|c|c|}
\hline Mix type & $\begin{array}{l}\text { Fine aggregate } \\
(\mathrm{kg})\end{array}$ & $\begin{array}{l}\text { Medium-size } \\
\text { aggregate }(\mathrm{kg})\end{array}$ & $\begin{array}{l}\text { Coarse aggregate } \\
(\mathrm{kg})\end{array}$ & Cement (kg) & Water $(\mathrm{kg})$ & $\begin{array}{l}\text { Total weight } \\
\left(\mathrm{kg} / \mathrm{m}^{3}\right)\end{array}$ \\
\hline $\begin{array}{l}\text { Basalt-based } \\
\text { concrete (BBC) }\end{array}$ & 843 & 334 & 667 & 350 & 210 & 2404 \\
\hline $\begin{array}{l}\text { Dolomite-based } \\
\text { concrete (DBC) }\end{array}$ & 675 & 588 & 547 & 350 & 210 & 2370 \\
\hline
\end{tabular}

for chemical resistance of mortars). Four types of acidic solutions were used: $5 \%$ sulfuric acid $\left(\mathrm{H}_{2} \mathrm{SO}_{4}\right)$; $10 \%$ hydrochloric acid $(\mathrm{HCl}) ; 5 \%$ nitric acid $\left(\mathrm{HNO}_{3}\right)$ and $10 \%$ acetic acid $\left(\mathrm{CH}_{3} \mathrm{COOH}\right)$, with the following $\mathrm{pH}$ values: $0.5,0.25,0.45$ and 2.2 , respectively.

For each acidic environment and curing age, three concrete slices were subjected to each solution. The concrete slices were immersed in plexi-glass containers containing these acidic solutions for 90 days. These containers were kept covered throughout the testing period to minimize evaporation. Three rock cubes of 50 $\mathrm{mm}$ size were also immersed in separate containers to evaluate the direct effect of these acidic on the rock itself.

After 2, 7, 14, 28, 56 and 90 days of immersion, each specimen was removed from the baths, brushed with a soft nylon brush, and rinsed in distilled water. This process removed loose surface material from the specimen. The specimen was then dried and weighed. The acid resistance was evaluated through measurement of the weight loss of the specimens determined as follows:

$$
\text { Weight loss }(\%)=\mathrm{W}_{\mathrm{o}}-\mathrm{W}_{\mathrm{i}} / \mathrm{W}_{\mathrm{o}}
$$

where, $W_{o}$ is the weight (in grams) of the specimens before immersion, $\mathrm{W}_{\mathrm{i}}$ is the weight (in grams) of cleaned specimens after $i$-day of immersion $(i=2,7$, 14, 28, 56 and 90 days). After weighing, each slice was then returned to the appropriate solution. At 90 days of immersion, all specimens were photographed. The evaluated concrete specimens were cured for 28 and 90 days respectively. The average value for three specimens was considered for assessment.

\subsubsection{Water Permeability Test}

Concrete permeability measured in terms of depth of water penetration was carried out as per the standard EN 12390-8. The basic procedure for such a depth of penetration is to apply water pressure ( 5 bars) to one surface of the specimen for a specific time $(72 \pm 2 \mathrm{~h})$ and then to split the specimen perpendicular to the injected face and determine visually the depth of penetration. Three $150 \mathrm{~mm}$ concrete cube specimens were tested after 28 and 90 days curing. The results shown in this paper were the average penetration depth.

\subsubsection{Rapid Chloride Penetrability Test}

The test was conducted in accordance with ASTM C 1202. The test measures the ease with which concrete allows the charge to pass through and gives an indication of the concrete resistance to chloride penetration. Three slices of $100 \mathrm{~mm}$ in diameter and 50 $\mathrm{mm}$ in thickness were epoxy-coated on ring surface and then vacuumed in a desiccator. The slice is then enclosed between two chambers, one containing a solution of $3 \%$ by mass sodium chloride acting a cathode and the other a $0.3 \mathrm{M} \mathrm{NaOH}$ solution acting an anode. The set-up of RCPT is illustrated in Fig. 7.

A $60 \mathrm{~V}$ dc electric field was continuously applied between the two chambers. The current was recorded at 30 min-intervals and the cell temperature was also monitored. The total charge passed through the sample, in coulombs, is determined by calculating the area under the current-time plot during the $6 \mathrm{~h}$ test period. It is generally agreed that for low-permeability concretes, the value of the charge, in coulombs, passed through the specimens should not exceed 2,000. Three cylinder specimens of each concrete mix were tested after 28 and 90 days curing.

\section{Results and Discussion}

\subsection{Properties of Basalt}

As seen from Table 3 and Fig. 3, crushed basalt rock is classified as basic basalt and can be considered as suitable material for use as aggregate. It satisfied the 


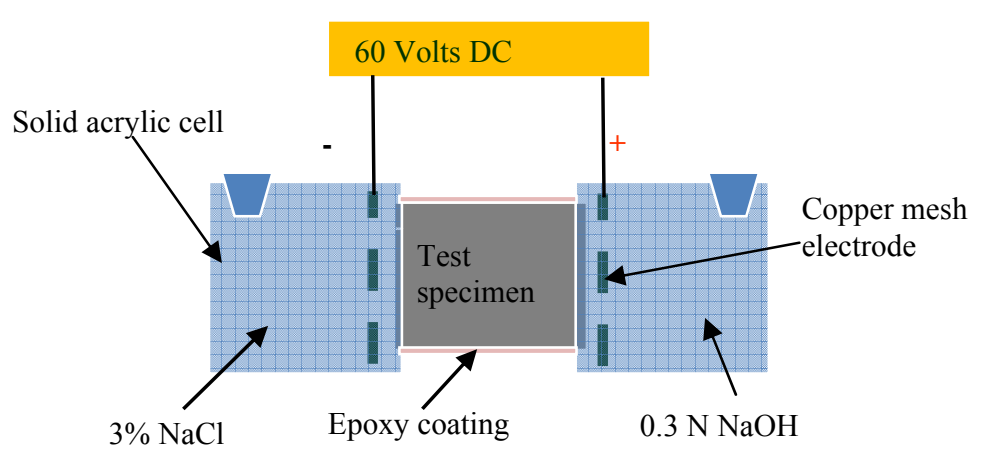

(a)

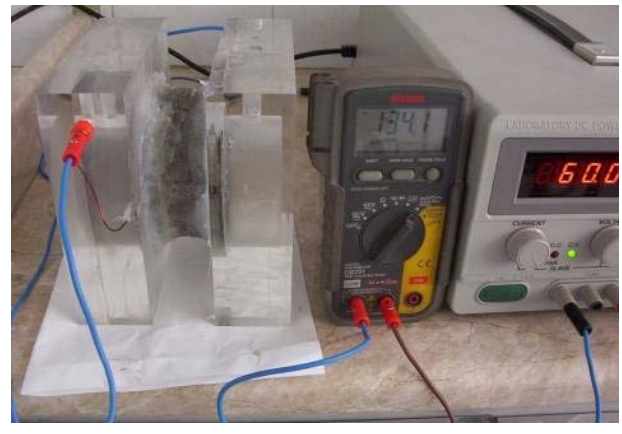

(b)

Fig. 7 Experimental setup of rapid chloride penetration test: (a) Schematic representation of experimental setup of rapid chloride penetration test; (b) View of experimental setup.

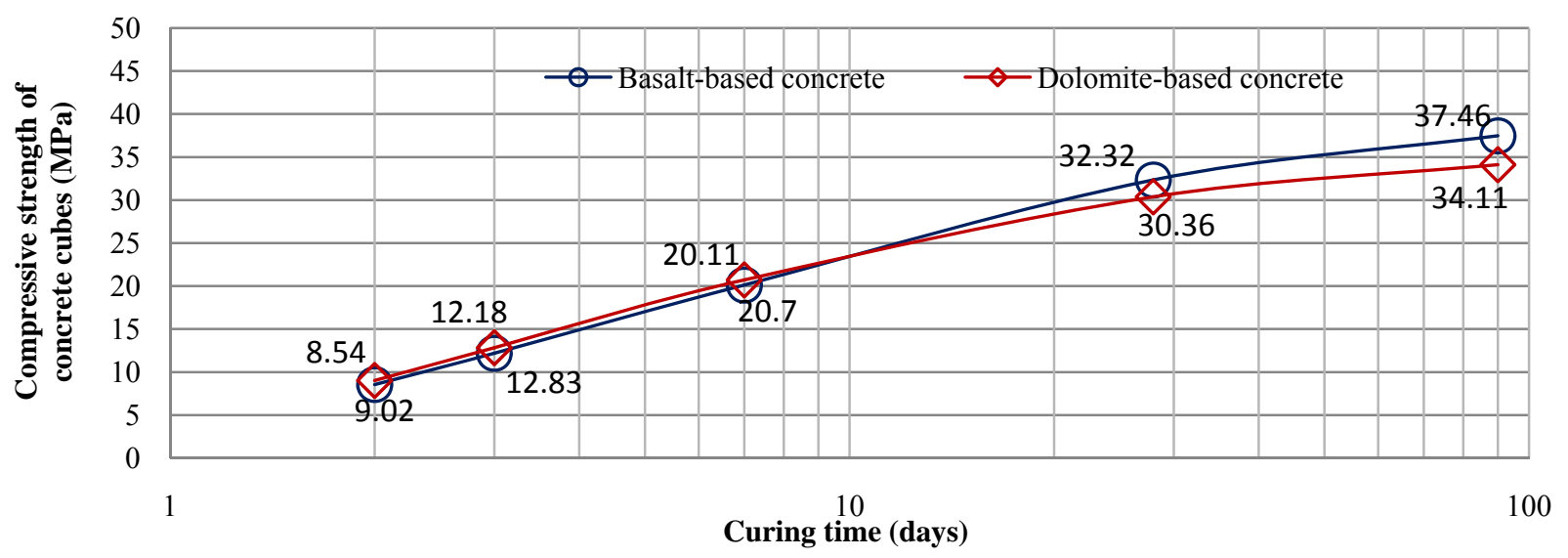

Fig. 8 Development of compressive strength of basalt- and dolomite-based concretes.

standards requirements for such a material by having a specific gravity of more than 2.6 , water absorption (\%) of less than $2 \%$, a sand equivalent of more than $70 \%$, a Los Angeles value (\%) of less than 45 and $\mathrm{Na}_{2} \mathrm{SO}_{4}$ soundness of less than 12 for coarse aggregates, respectively. In addition, the chemical composition of basalt aggregates, as shown in Table 1, is also in conformity with the standards requirements. Their contents of $\mathrm{Cl}^{-}$and $\mathrm{SO}_{3}$ are less than $0.05 \%$ and $0.2 \%$, respectively. According to ASTM 1260 crushed basalt aggregates can be classified as non-reactive aggregates. Its expansion of less than $0.1 \%$ is indicative of innocuous behavior in most cases.

\subsection{Compressive Strength of Concretes}

The development of the compressive strength with age of BBC (Basalt-based concrete) and DBC (Dolomite-based concrete) is shown in Fig. 8. As expected, the compressive strength of the concrete increases with curing time with a high rate of strength gain at early ages which gradually decreases at longer ages. BBC specimens have higher compressive strengths beyond 7 days when compared with DBC ones. The relatively higher compressive strength of $\mathrm{DBC}$ at early ages may be due to some interfacial chemical reactions which may improve the bond strength [4, 30]. In return, the higher compressive strength of $\mathrm{BBC}$ beyond 7 days could not be easily explained in the normal strength concrete. Tasong et al. 1998 [3] indicated to the higher apparent interfacial bond strength in basalt when compared with dolomite. Furthermore, according to authors, crushed basalt is more angular and rougher than dolomite. This may make the ITZ (interfacial transition zone) when using basalt more compacted, and thereby the bond between the hydrated cement and aggregate becomes stronger. 


\subsection{Acidic Attack Resistance}

Acids attack concrete by dissolving cement paste and calcareous aggregates [31]. Although acids generally attack and leach away the calcium compounds of the cement paste, they may not readily attack certain aggregates, such as siliceous aggregates. Calcareous aggregates often react readily with acids. However, the sacrificial effect of calcareous aggregate is often a benefit over siliceous aggregate in mild acid exposure in areas where water is not flowing. With calcareous aggregate, the acid attacks the entire exposed concrete surface uniformly, reducing the rate of attack on the paste and preventing loss of aggregate particles at the surface. Calcareous aggregates also tend to neutralize the acid, especially in stagnant locations [31].

\subsubsection{Sulfuric Acid Attack}

Sulfuric acid attack on concrete can occur in various ways as shown in Table 1. Sulfuric acid is very damaging to concrete as it combines an acid attack and a sulfate attack [32]. At the first stage, deterioration of $\mathrm{Ca}(\mathrm{OH})_{2}$ results with expansive gypsum formation. The gypsum then reacts with $\mathrm{C}_{3} \mathrm{~A}$ in aqueous environment and forms a more expansive product called ettringite. These very expansive compounds cause internal pressure in the concrete which leads to the formation of cracks [33], and the transformation of the concrete into a mushy or a non-cohesive mass [34]. Sulfuric acid may also cause the decalcification of Calcium silicate hydrates C-S-H and will ultimately transform the C-S-H into amorphous hydrous silica. The following equations express these reactions [33]:

$$
\begin{gathered}
\mathrm{Ca}(\mathrm{OH})_{2}+\mathrm{H}_{2} \mathrm{SO}_{4} \rightarrow \mathrm{CaSO}_{4} \cdot 2 \mathrm{H}_{2} \mathrm{O} \text { (gypsum) } \\
3\left(\mathrm{CaSO}_{4} \cdot 2 \mathrm{H}_{2} \mathrm{O}\right)+3 \mathrm{CaO} \cdot \mathrm{Al}_{2} \mathrm{O}_{3} \cdot 12 \mathrm{H}_{2} \mathrm{O}+14 \mathrm{H}_{2} \mathrm{O} \rightarrow \\
3 \mathrm{CaO} . \mathrm{Al}_{2} \mathrm{O}_{3} \cdot 3 \mathrm{CaSO}_{4} \cdot 32 \mathrm{H}_{2} \mathrm{O}_{3} \text { (ettringite) } \\
\mathrm{CaO} \cdot \mathrm{SiO}_{2} \cdot 2 \mathrm{H}_{2} \mathrm{O}+\mathrm{H}_{2} \mathrm{SO}_{4} \rightarrow \mathrm{CaSO}_{4}+ \\
\mathrm{Si}(\mathrm{OH})_{4} \text { (hydrous silica) }+\mathrm{H}_{2} \mathrm{O}
\end{gathered}
$$

The white gypsum which covers the surface of concrete can potentially lead to a blocking of pores at the surface, leading to a slower rate of attack initially. However, this effect lasts only temporarily [35].
Fig. 9 displays the result of weight loss of BBC specimens due to the $5 \%$ sulfuric acid attack, and the weight loss is considered as a function of time. The results have revealed that the $\mathrm{BBC}$ specimens have suffered more deterioration in terms of weight loss when immersed in $5 \% \mathrm{H}_{2} \mathrm{SO}_{4}$ than DBC specimens. This was in conformity with the literature $[12,36]$. The weight loss of 28 and 90 days cured $\mathrm{BBC}$ specimens, after 90 days of immersion in $5 \% \mathrm{H}_{2} \mathrm{SO}_{4}$, was $14 \%$ and $15 \%$, respectively. In the case of DBC specimens, it was $9 \%$ and $9.5 \%$ after 28 and 90 days curing, respectively. Contrary to expectation, the weight loss increased when the curing age increased from 28 to 90 days. This unexpected situation could not be easily explained. However, according to authors, this can be attributed to the higher calcium hydroxide formed during the longer-term hydration. According to Fattuhi \& Hughes [13], the higher the lime content, the higher the rate of attack. The weight loss of $10 \%$ was obtained with $\mathrm{BBC}$ at up to about 15 days of exposure to $5 \%$ sulfuric acid, but the DBC specimens didn't achieve the same loss even after 90 days of exposure.

In addition, the concrete surface in the case of DBC samples is relatively smooth indicating that the attack occurred to both cement mortar and dolomite aggregates. However, in BBC specimens, the cement mortar has been only attacked and the effect of neutralization during acid attack would be very limited. This was confirmed by the highly acid resistance of basalt rock and the substantial deterioration of the dolomite rock when immersed in the sulfuric acid solution. This situation which created less debris in DBC specimens is preferable in areas where water is not flowing. This is in a good agreement with results of Hughes and Guest [37]. It should be also noted that there are white and brown spots as shown in the Fig. 9. The white spots of deteriorated BBC \& DBC specimens may exhibit the presence of gypsum and ettringite [38]. The brown spots may indicate to the presence of hydrated ferric oxide [39]. 


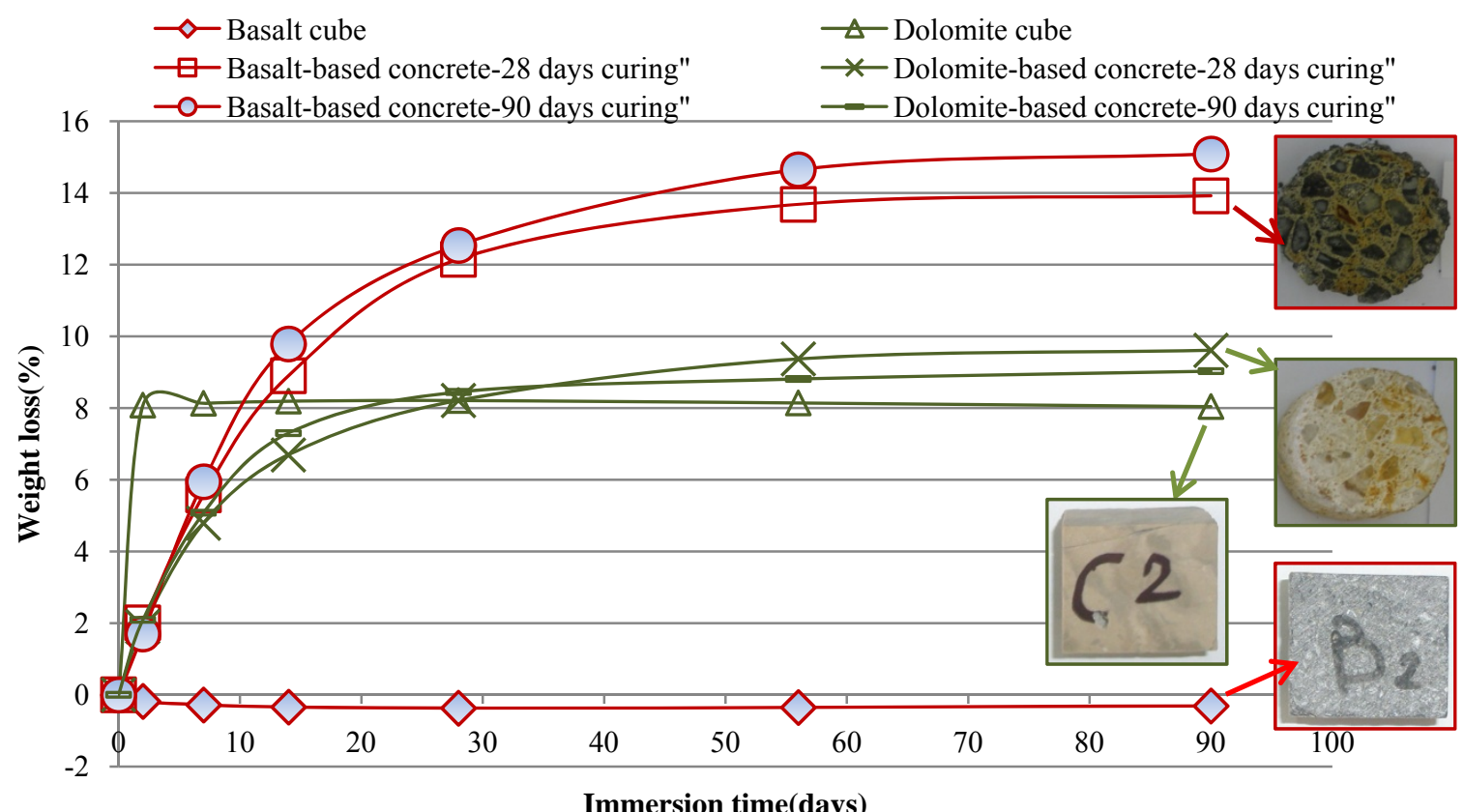

Fig. 9 Weight losses over time of concrete and rock specimens immersed in $5 \% \mathrm{H}_{2} \mathrm{SO}_{4}$.

\subsubsection{Hydrochloric Acid Attack}

The action of $\mathrm{HCl}$ on cement hydration products, in particular $\mathrm{Ca}(\mathrm{OH})_{2}$ and the resulting products are presented in the following chemical equation:

$$
\mathrm{Ca}(\mathrm{OH})_{2}+2 \mathrm{HCl} \rightarrow \mathrm{CaCl}_{2}+2 \mathrm{H}_{2} \mathrm{O}
$$

It can be seen from the Eq. (5) that, consumption of $\mathrm{Ca}(\mathrm{OH})_{2}$ results with formation of salt of $\mathrm{CaCl}_{2}$. By the help of water, this highly soluble salt may be easily transported to the outer parts of concrete. In this situation, continuous reactions increase the porosity of cement paste and increased pore volume speeds up the rate of reaction [40]. According to Baron and Ollivier [41], a further reaction may occur between $\mathrm{CaCl}_{2}$ and $\mathrm{C}_{3} \mathrm{~A}$ which leads to the formation of chloroaluminate and ettringite. This reaction results in a substantial expansion. The weight losses versus day time of BBC, DBC and rock specimens due to the $10 \%$ hydraulic acid attack were plotted in Fig. 10. The results have revealed that the degree of deterioration in terms of loss weight was obviously greater with $\mathrm{DBC}$ specimens than $\mathrm{BBC}$ ones.

The weight loss of 28 and 90 days cured $\mathrm{BBC}$ specimens, after 90 days of exposure to $10 \% \mathrm{HCl}$, was
$8.6 \%$ and $11 \%$ respectively. However, in DBC specimens it was $22.6 \%$ and $24.8 \%$ for 28 and 29 days cured DBC, respectively. Contrary to expectation, the weight loss increased when the curing age increased from 28 to 90 days. This unexpected situation could be also explained in a manner similar to what was mentioned earlier in sulfuric acid attack. The weight loss of $10 \%$ was obtained with 90 days cured BBC at up to 30 days of exposure to $10 \%$ hydrochloric acid, but the 28 days cured BBC specimens didn't achieve the same loss even after 90 days of exposure. By contrast, DBC specimens reached the same weight loss at the next day of exposure to the acid solution.

Contrary to sulfuric acid attack, the concrete surface in both $\mathrm{DBC}$ and $\mathrm{BBC}$ specimens were relatively smooth indicating that the attack occurred to both cement mortar and aggregates. This situation was clearer in DBC specimens compared to BBC ones. The disintegration of the dolomite rock specimen and the partially contribution of the basalt rock in the weight loss could, to some extent, explain this result. The increased strength and the decreased permeability of $\mathrm{BBC}$ is the most likely reasons resulting to the better 


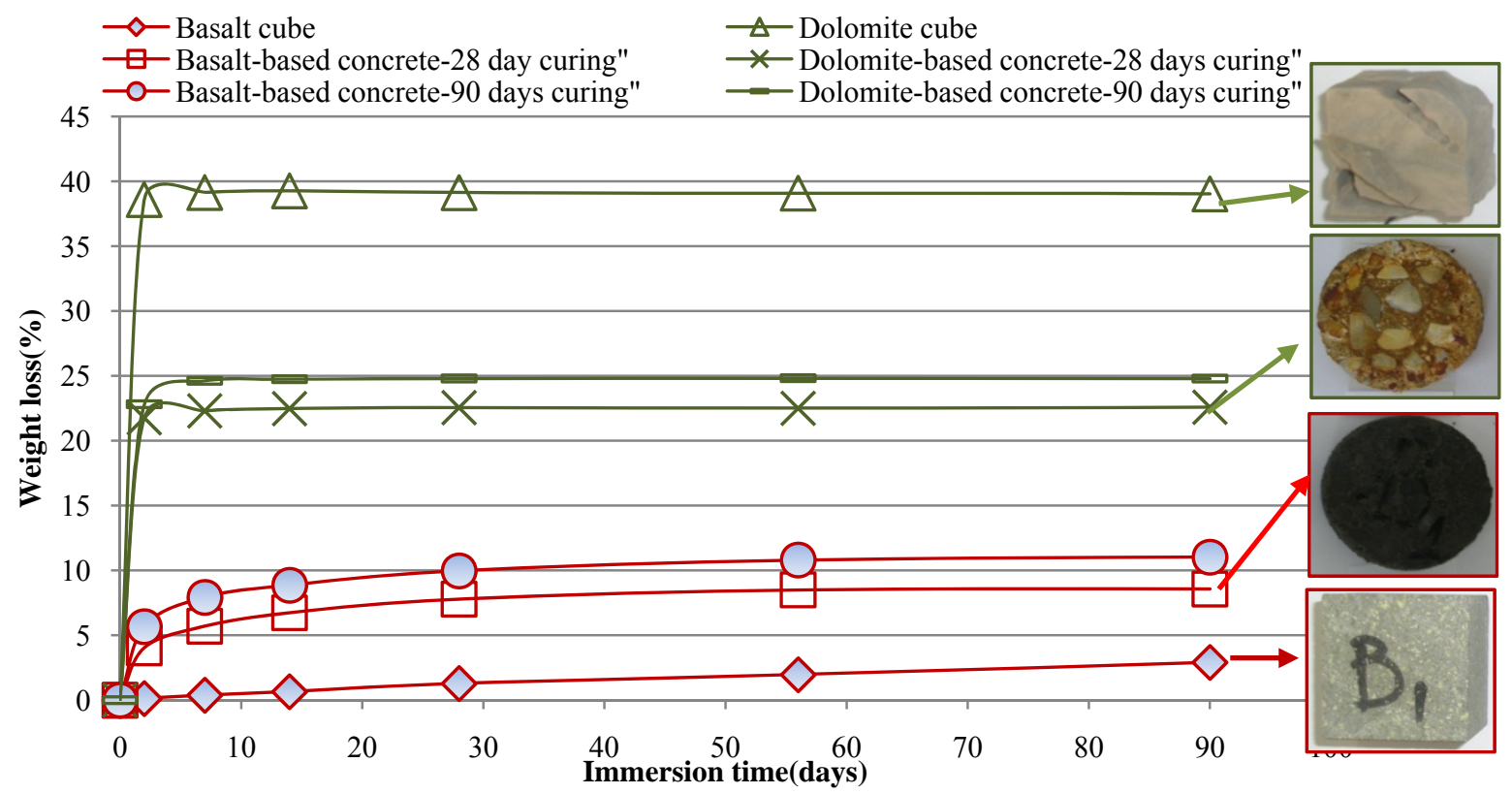

Fig. 10 Weight losses over time of concrete and rock specimens immersed in $10 \% \mathrm{HCl}$.

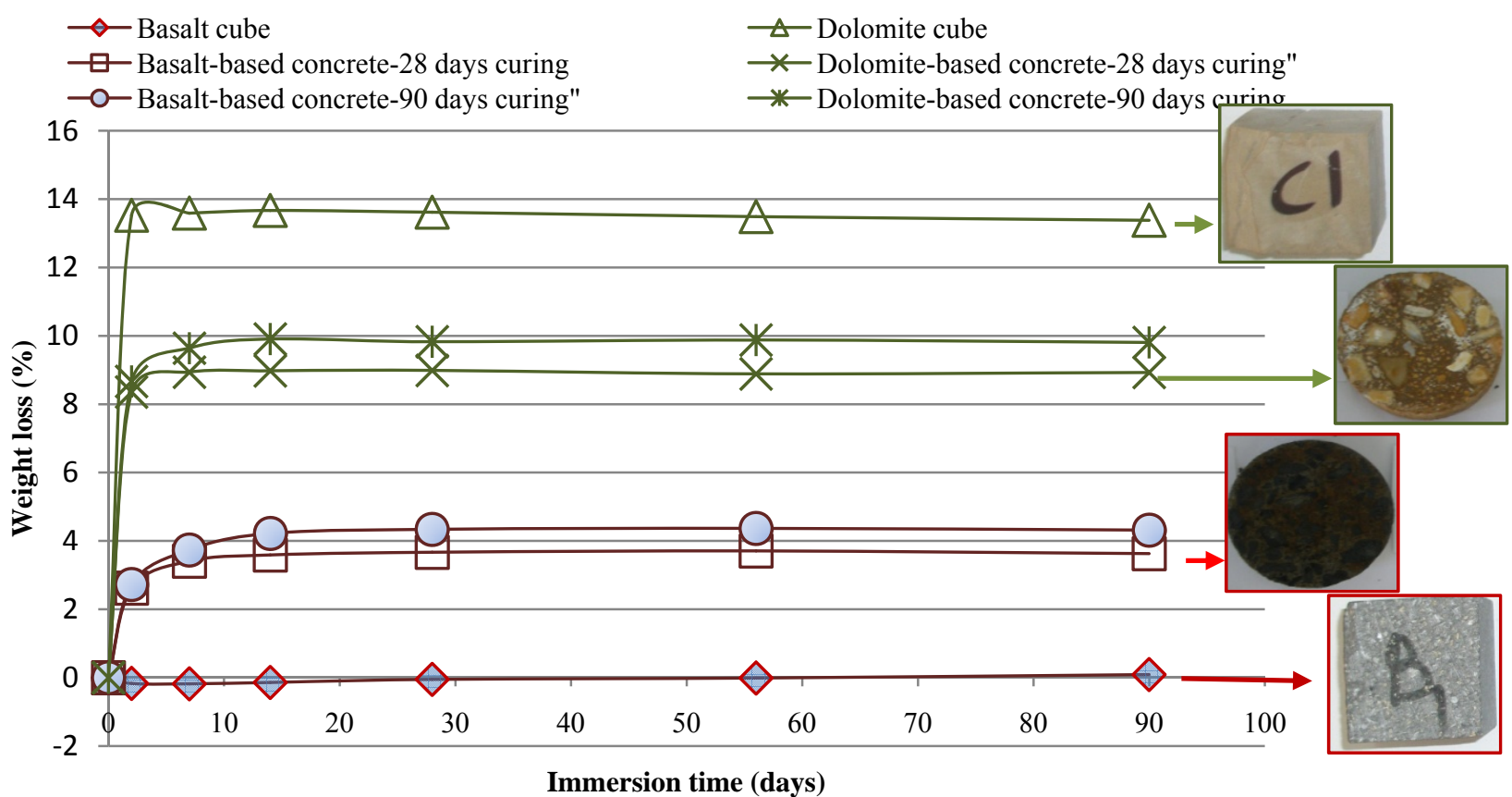

Fig. 11 Weight losses over time of concrete and rock specimens immersed in $5 \% \mathrm{HNO}_{3}$.

protection provided by crushed basalt. So, in $\mathrm{HCl}$-containing environments, $\mathrm{BBC}$ specimens might be more preferable in areas where water is not flowing

\subsubsection{Nitric Acid Attack}

The reaction of calcium hydroxide with nitric acid results in the formation of calcium nitrate as in the following chemical equation [16]:

$$
\mathrm{Ca}(\mathrm{OH})_{2}+2 \mathrm{HNO}_{3} \rightarrow \mathrm{Ca}\left(\mathrm{NO}_{3}\right)_{2}+2 \mathrm{H}_{2} \mathrm{O}
$$

It can be seen from the Eq. (6) that consumption of $\mathrm{Ca}(\mathrm{OH})_{2}$ results with formation of $\mathrm{Ca}\left(\mathrm{NO}_{3}\right)_{2}$. This salt is highly soluble and so is rapidly removed from the corroded layer, leaving behind porosity [42]. Moreover, as the process of acid attack progresses, aluminum nitrate and iron (III) nitrate are formed. 
These products are also highly soluble. In the nitric acid attack on concrete, there is a relatively substantial shrinkage of the corroded layer, which leads to cracking and a further increase in the porosity of the corroded layer [42].

The weight losses versus day time of $\mathrm{BBC}, \mathrm{DBC}$ and rock specimens due to the $5 \%$ nitric acid attack were plotted in Fig. 11. The results have revealed that the degree of deterioration in terms of loss weight was obviously greater with $\mathrm{DBC}$ specimens than $\mathrm{BBC}$ ones.

The weight loss of 28 and 90 days cured BBC specimens, after 90 days of exposure to $5 \% \mathrm{HNO}_{3}$, was $3.6 \%$ and $4.3 \%$ respectively. In return, in DBC specimens it was $8.9 \%$ and $9.8 \%$ for 28 and 29 days cured DBC, respectively. Contrary to expectation, the weight loss increased when the curing age increased from 28 to 90 days. This unexpected situation could be also explained in a manner similar to what was mentioned earlier in both attacks (sulfuric and hydrochloric acid)

The weight loss of $10 \%$ was not obtained with all concrete specimens even after 90 days of immersion. The dolomite rock specimen is the only one that reached the same weight loss at the next day of exposure to the acid solution. No weight loss was recorded in basalt rock specimen even after 90 days of exposure. According to authors, the better protection provided by crushed basalt rock could be attributed to the highly acid resistance of the rock itself and, to some degree, to the lower water permeability of $\mathrm{BBC}$ specimen as reported below.

As shown in Fig. 11, the corroded layer is soft and porous with visible cracks. The color of such a corroded layer is white with brown spots. The white zone may contain a high content of $\mathrm{SiO}_{2}$, while the brown spots may be due to the formation of hydrated ferric oxide. In addition, it was clearly noted the relatively substantial shrinkage of the corroded layer in the dolomite rock specimen. This is in a good agreement with the results of Pavlic [43].

\subsubsection{Acetic Acid}

Organic acids are likely to react with the different hydrated and anhydrous compound of the cement paste (calcium hydroxide, C-S-H, hydrated aluminates, $\mathrm{C}_{3} \mathrm{~S}$, $\mathrm{C}_{2} \mathrm{~S}$ ). For example, Bensted [44] supposed that acetic acid was involved in at least three reactions during its action on the cementitious matrix:

$$
\begin{gathered}
2 \mathrm{CH}_{3} \mathrm{COOH}+\mathrm{Ca}(\mathrm{OH})_{2} \rightarrow \\
\mathrm{Ca}\left(\mathrm{CH}_{3} \mathrm{COO}\right)_{2}+2 \mathrm{H}_{2} \mathrm{O} \\
6 \mathrm{CH}_{3} \mathrm{COOH}+3 \mathrm{CaO} \cdot 2 \mathrm{SiO}_{2} \cdot 3 \mathrm{H}_{2} \mathrm{O} \rightarrow \\
3 \mathrm{Ca}\left(\mathrm{CH}_{3} \mathrm{COO}\right)_{2}+2 \mathrm{SiO}_{2} \cdot \mathrm{aq}+\mathrm{nH}_{2} \mathrm{O} \\
6 \mathrm{CH}_{3} \mathrm{COOH}+3 \mathrm{CaO} \cdot \mathrm{Al}_{2} \mathrm{O}_{3} \cdot 6 \mathrm{H}_{2} \mathrm{O} \rightarrow \\
3 \mathrm{Ca}\left(\mathrm{CH}_{3} \mathrm{COO}\right)_{2}+\mathrm{Al}_{2} \mathrm{O}_{3} \cdot \mathrm{aq}+\mathrm{nH}_{2} \mathrm{O}
\end{gathered}
$$

The weak acids owing to their low dissociation degree, achieve higher $\mathrm{pH}$ values [45]. Acetic acid combines with the hardened cement to form soluble compounds which, on removal, leave exposed aggregate. Household vinegar is ordinarily a 5\% solution of acetic acid, but even a $2 \%$ or weaker solution can be injurious to concrete.

Fig. 12 displays the weight losses versus day time of BBC, DBC and rock specimens due to the $10 \%$ acetic acid attack. The results have revealed that the BBC specimens have lost less weight compared to the BBC ones. The weight loss of 28 and 90 days cured BBC specimens, after 90 days of exposure to $10 \%$ $\mathrm{CH}_{3} \mathrm{COOH}$, was $3.2 \%$ and $3.5 \%$ respectively. In DBC specimens it was $9.5 \%$ and $10.4 \%$ for 28 and 90 days cured DBC, respectively. Contrary to expectation, the weight loss increased when the curing age increased from 28 to 90 days. This unexpected situation could be also explained in a manner similar to what was mentioned earlier in all acidic attacks. The weight loss of $10 \%$ was not obtained with all BBC specimens even after 90 days of immersion. The 90-cured DBC specimen is the only concrete one that reached the same weight loss after 56 days of exposure to the acid solution. No weight loss was recorded in basalt rock specimen even after 90 days of exposure to $10 \% \mathrm{CH}_{3} \mathrm{COOH}$, whereas, the dolomite rock specimen has suffered a severe deterioration. The better protection provided 
Concrete Containing Crushed Basalt as Aggregates

by crushed basalt rock could be also attributed to the highly acid resistance of the rock itself and to some degree to the lower water permeability of $\mathrm{BBC}$ specimen as reported in the paper.

As shown in Fig. 12 , the acetic acid attack resulted in the formation of a light brown corroded layer corroded layer. This brown layer may be due to the formation of hydrated ferric oxide.

\subsubsection{Correlation between Acidic Attacks}

Figs. 13-18 show correlations between different acidic attacks. It showed be noted from Figs. 13-18, that the deterioration in terms of weight loss of DBC specimens exposed to $5 \% \mathrm{H}_{2} \mathrm{SO}_{4}$ was the smallest.

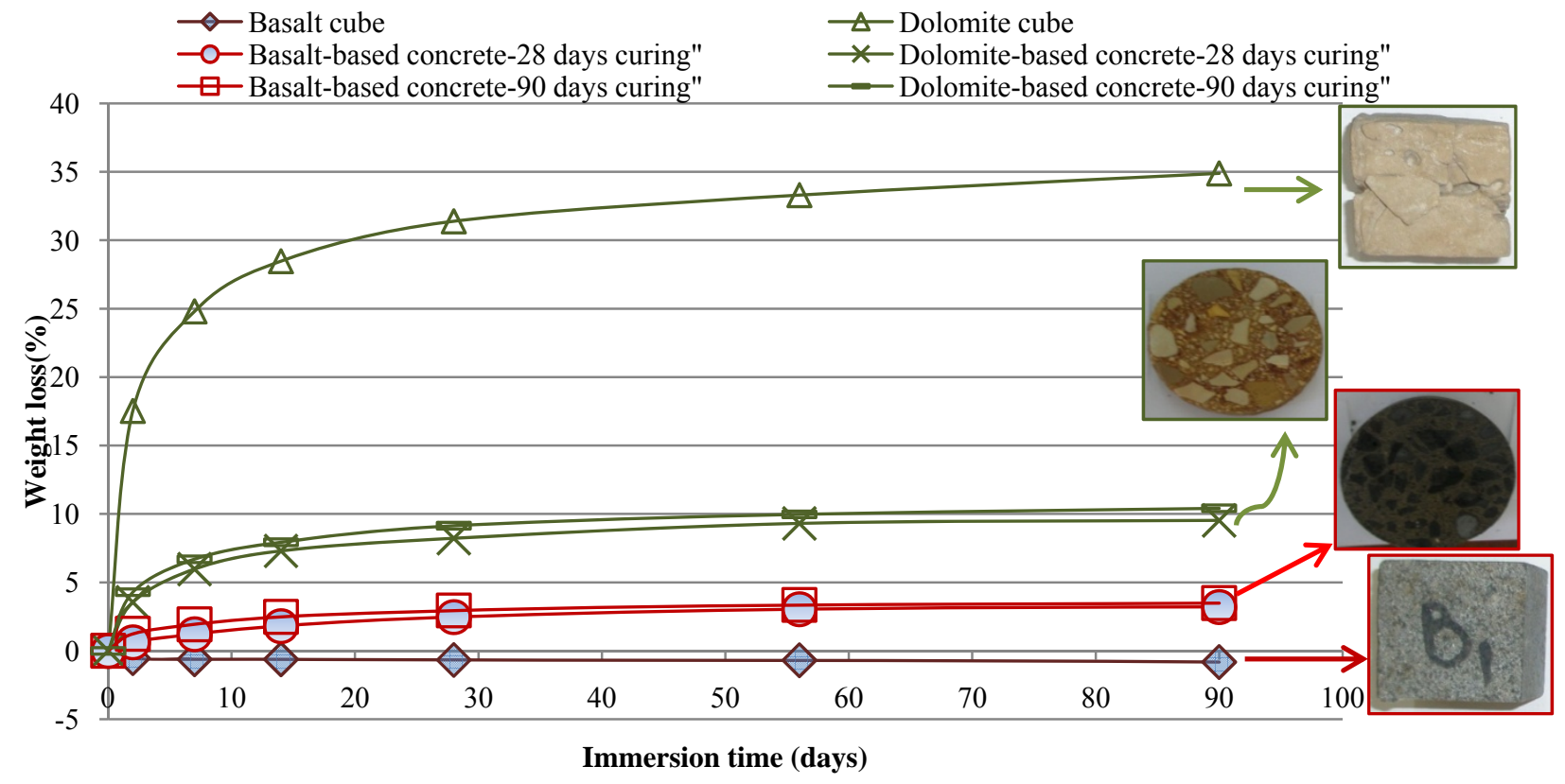

Fig. 12 Weight losses over time of concrete and rock specimens immersed in $10 \% \mathrm{CH}_{3} \mathrm{COOH}$.

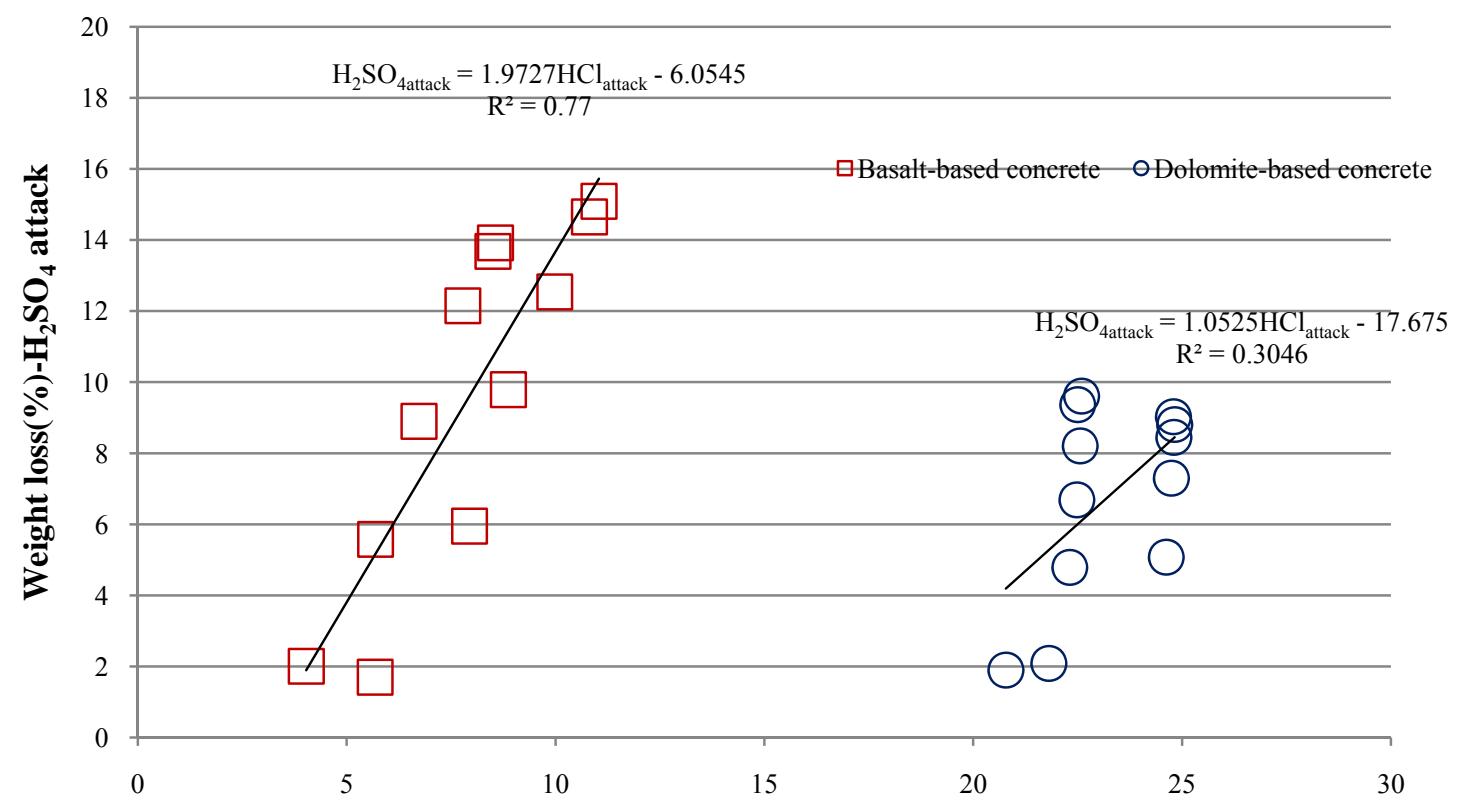

Weight loss(\%)-5\% HCl attack 
Fig. 13 Sulfuric acid versus hydrochloric acid.

This was due to the lowest solubility of calcium sulfate (gypsum) in water than calcium chloride, calcium nitrate and calcium acetate. Solubility of $\mathrm{CaSO}_{4}, \mathrm{CaCl}_{2}, \mathrm{Ca}\left(\mathrm{NO}_{3}\right)_{2}$ and $\mathrm{Ca}\left(\mathrm{CH}_{3} \mathrm{COO}\right)_{2}$ are $0.2 \%$, $46.08 \%, 56.0 \%$ and $52.0 \%$ (by weight) respectively [11]. By contrast, the deterioration in terms of weight loss of BBC specimens exposed to $5 \% \mathrm{H}_{2} \mathrm{SO}_{4}$ was the biggest. The only component which suffered from the attack was the hydrated cement, whereas the crushed basalt was not affected.

As illustrated in Figs. 13-15, there were, contrary to expectation, acceptable to strong correlations between sulfuric attack and all other acidic attacks on BBC specimens, with correlation coefficients $\mathrm{R}^{2}$ ranging from 0.68 to 0.93 . This was despite the different mechanism of deterioration. In the sulfuric acid, expansive calcium salts of lower solubility are formed and followed by cracking and eventual transformations of mortar into a mushy or non-cohesive mass [33]. In return, the calcium salts in $\mathrm{HCl}, \mathrm{HNO}_{3}$ and $\mathrm{CH}_{3} \mathrm{COOH}$ are highly soluble, and may easily leach away. In addition, the $5 \% \mathrm{H}_{2} \mathrm{SO}_{4}$ solution was found to be at early days of exposure, less corrosive than $10 \% \mathrm{HCl}$ and $5 \% \mathrm{HNO}_{3}$. This can be due to the formation of large amounts of gypsum that crystallized in the pores of the specimens and near the surface, thereby blocking further reactions [18]. However, this behavior lasted temporarily.

It should be also noted from Figs. 13-18, that all BBC specimens exhibited acceptable to strong correlations between all acid attacks. By contrast, the only strong correlations in case of DBC specimens were observed in $\mathrm{H}_{2} \mathrm{SO}_{4}$ versus $\mathrm{CH}_{3} \mathrm{COOH}$ and $\mathrm{HCl}$ versus HNO3 attacks. However, if the concentrations were changed, different behavior might be observed. Among the strong linear correlations, there was observed a strong correlation between $\mathrm{HCl}$ and $\mathrm{CH}_{3} \mathrm{COOH}$ attacks on $\mathrm{BBC}$ as illustrated in Fig. 17. This was in a good agreement with result of [46]. The hydrochloric acid attack was more corrosive than acetic acid attack. The weight loss in $\mathrm{HCl}$ attack was approximately thrice when compared with $\mathrm{CH}_{3} \mathrm{COOH}$

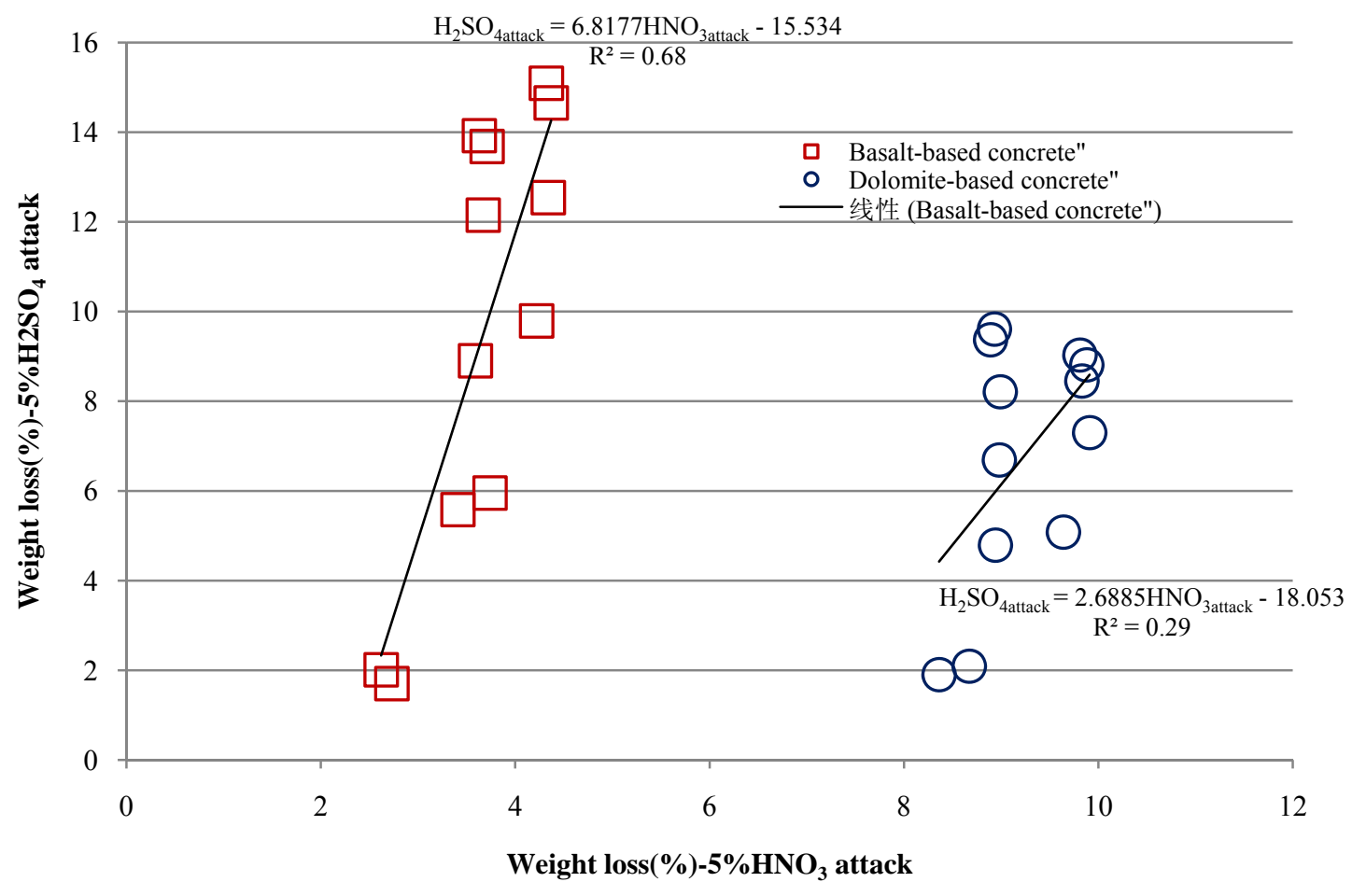


Fig. 14 Sulfuric acid versus nitric acid.

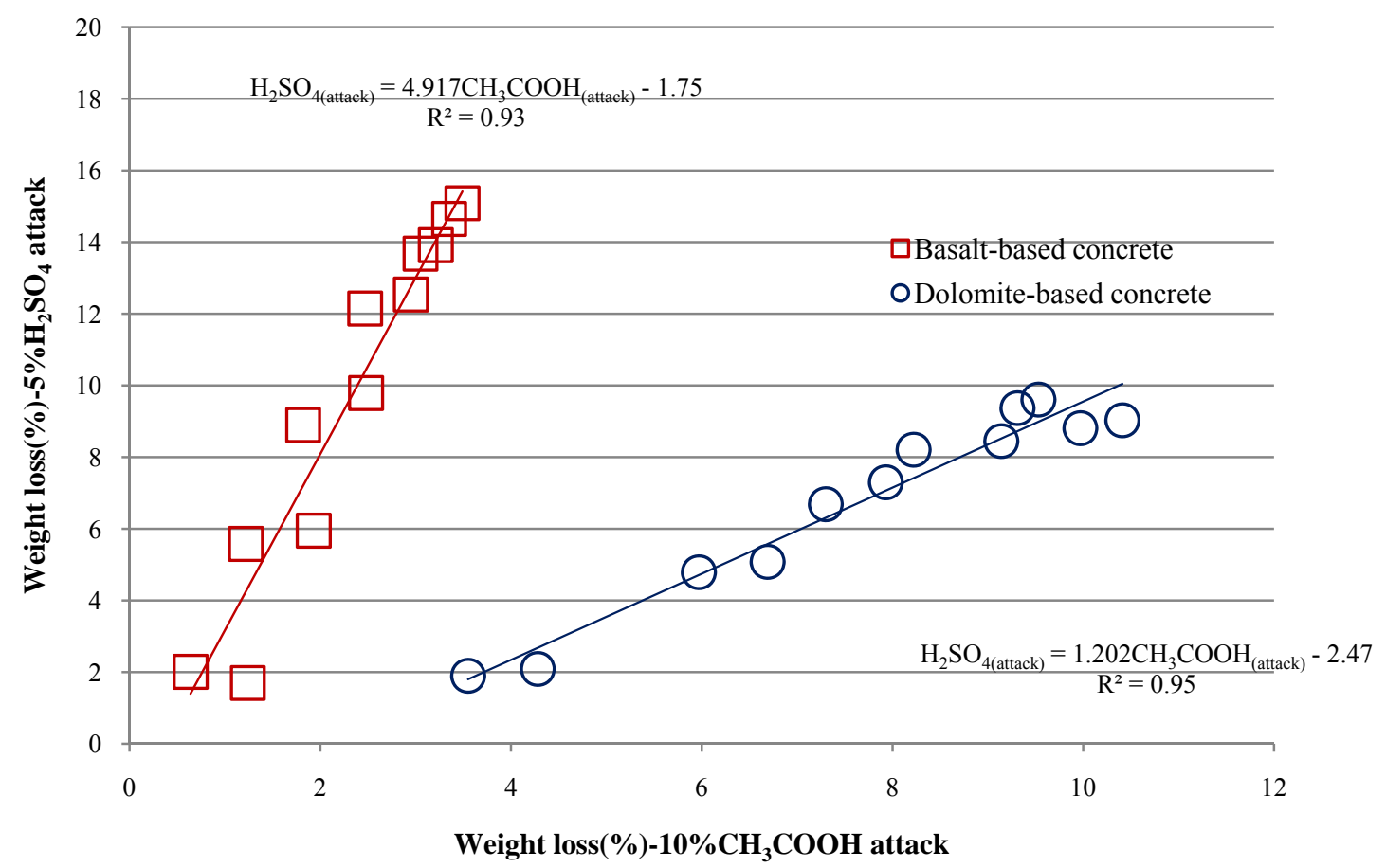

Fig. 15 Sulfuric acid versus acetic acid.

attack. An acceptable linear correlation $\left(\mathrm{R}^{2}=0.71\right)$ was also observed between nitric and acetic acid attacks, as shown in Fig. 18. It should be noted from Fig. 18 that $\mathrm{HNO}_{3}$ is also more corrosive than acetic attack even with a lower concentration. Furthermore, as illustrated in Figs 13-18, the attack by acetic acid was the weakest. This was due to the highest $\mathrm{pH}$ value of acetic acid solution.

\subsection{Water Permeability of Concrete}

Water penetration depth can be considered as an indication of permeable and impermeable concrete [10]. A depth of less than $50 \mathrm{~mm}$ classifies the concrete as impermeable and a depth of less than $30 \mathrm{~mm}$ as impermeable under aggressive conditions [10]. Fig. 7 shows the water penetration depth test results for both $\mathrm{BBC}$ and DBC specimens. Increasing the moist-curing period of concrete from 28 to 90 days reduced water penetration depths of all concretes by a factor of about 2 for both concretes containing basalt and dolomite aggregates. This result is in good agreement with the findings in the literature [10]. All concretes, except DBC specimens after 28 days curing, were found to be impermeable after 28 and 90 days curing. However, BBC specimens can be considered -after 90 days curing- as impermeable even under aggressive conditions, according to Neville [10]. The reason for the reduced permeability of $\mathrm{BBC}$ is believed to be the relatively high compacted ITZ of the hydrated cement and crushed basalt [47] which is relatively more angular, rougher and less water absorbent than crushed dolomite.

\subsection{Rapid Chloride Penetrability}

Rapid chloride penetrability was measured by the total charge (expressed as coulomb) passed through a slice of concrete cylinder in six hours. The results are shown in Fig. 8. The resistance to chloride penetration was greatly increased with the use of BBC. The total charge passed is substantially reduced with increasing curing time. The total charge passed through concrete mix containing basalt aggregates after $28 \& 90$ days 
curing was about two-third of the DBC mix. None of concretes has a total charge passed less than 2000 coulombs after 28 days. This expected result may be due to the used high w/b ratio. However, BBC specimens showed the best performance among all the specimens. According to ASTM C1202, these concretes can be considered as low chloride permeable after 90 days curing. The improvement in resistance to chloride penetration may be related to the relatively high compacted ITZ in BBC specimens and their reduced electrical conductivity.

\subsection{Chloride Penetrability versus Water Permeability of Concrete}

Fig. 11 shows the variation of total charge passed through concrete specimens (in Coloumbs) with depth

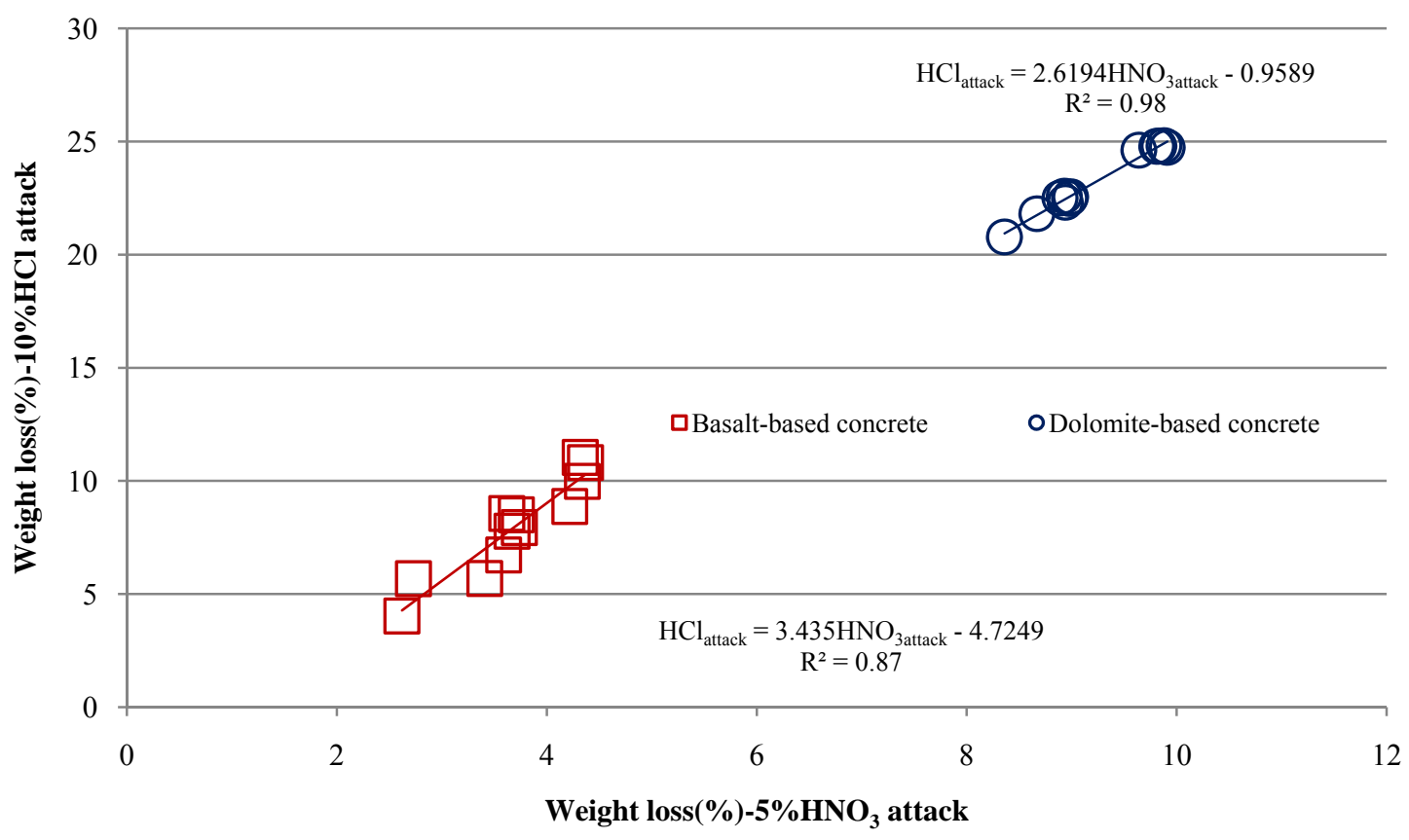

Fig. 16 Hydrochloric acid versus nitric acid.

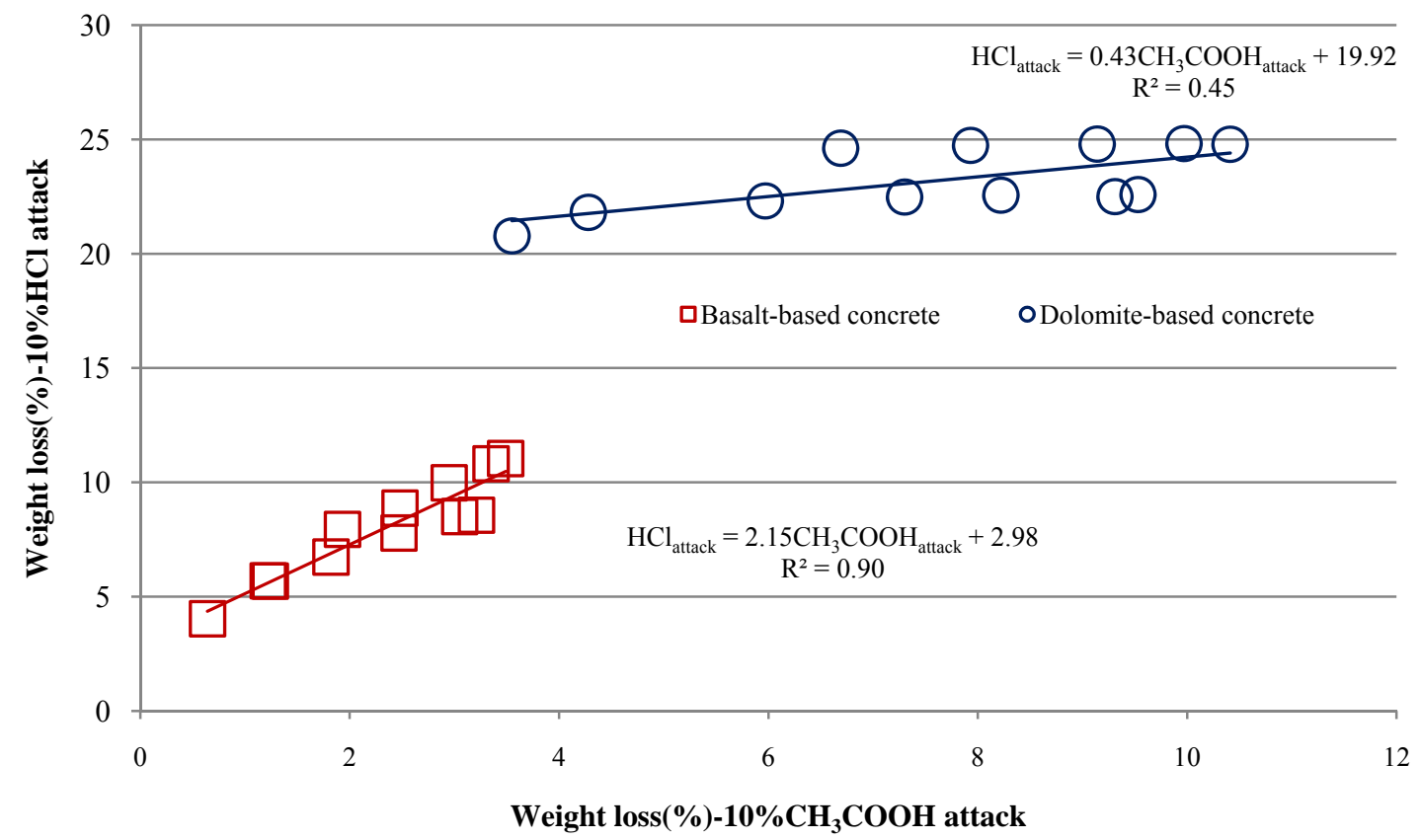


Fig. 17 Hydrochloric acid versus acetic acid.

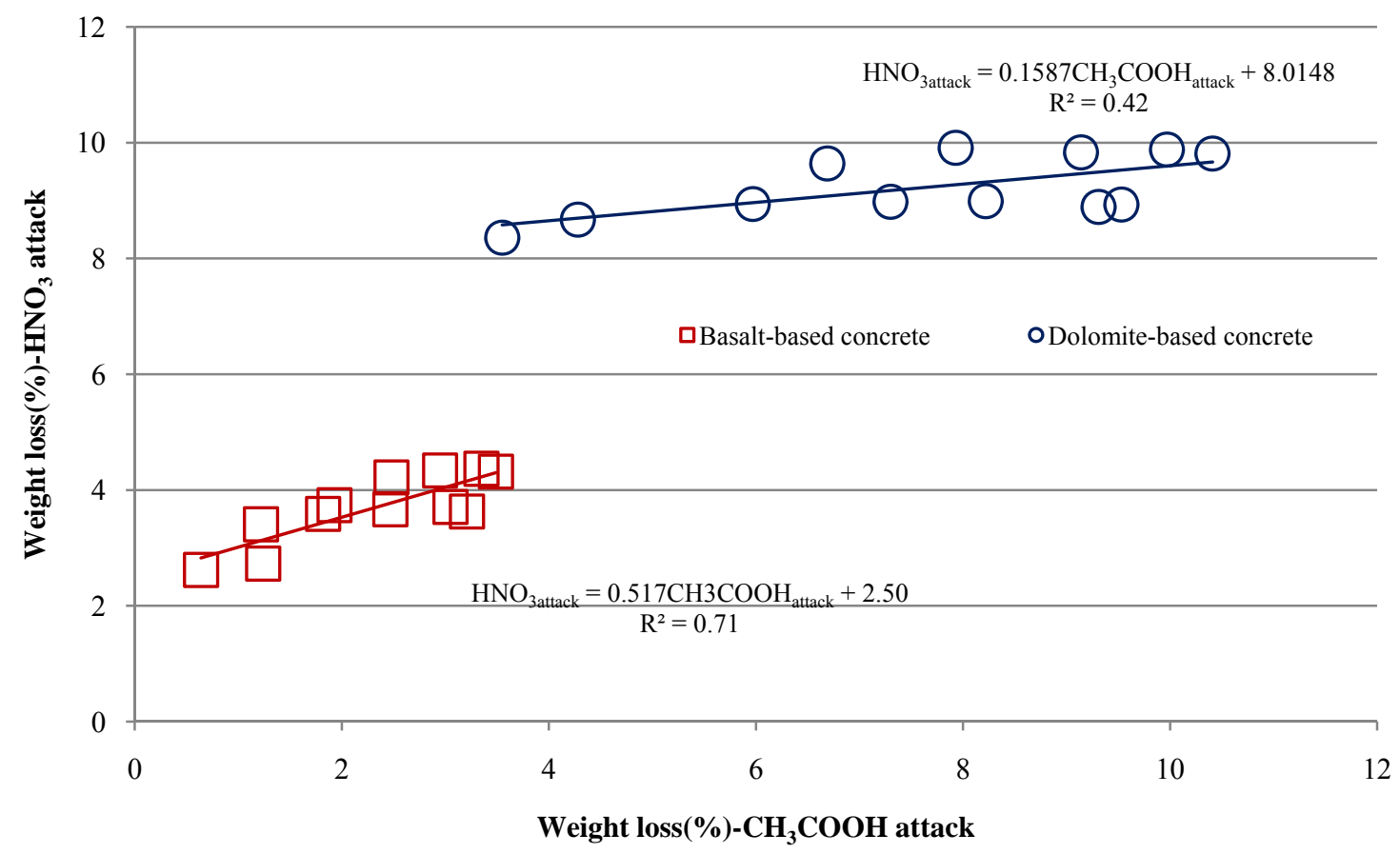

Fig. 18 Nitric acid versus acetic acid.

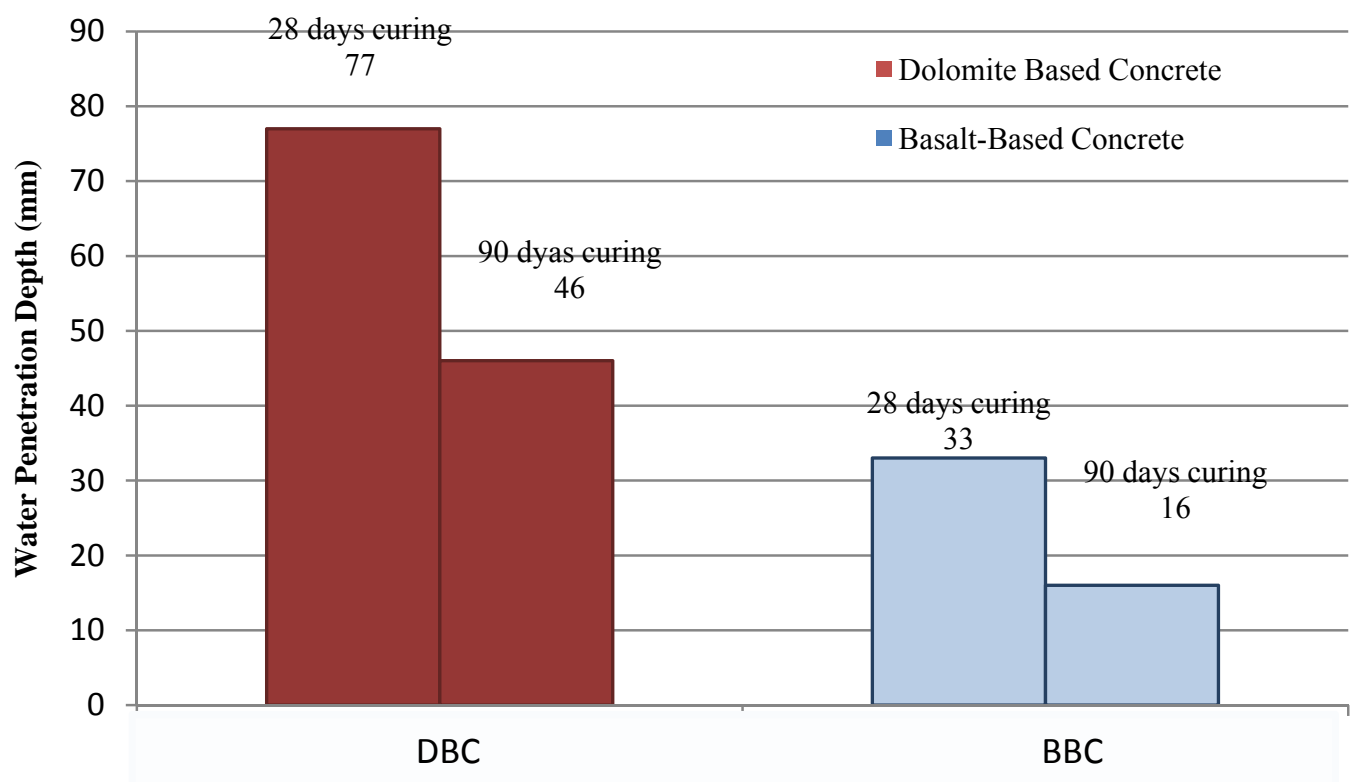

Type of concrete

Fig. 19 Water penetration depth.

of water penetration. It was noted from the graph that the rapid chloride penetrability clearly correlates to the water permeability of concrete after 28 \& 90 days curing. As shown in Fig. 10, there is a "perfect" fit $\left(\mathrm{R}^{2} \approx 1\right)$ between the penetration depth and the total charge passed. This suggests that the water 
permeability data may be used to predict the concrete

resistance to the chloride ion penetration and vice versa.

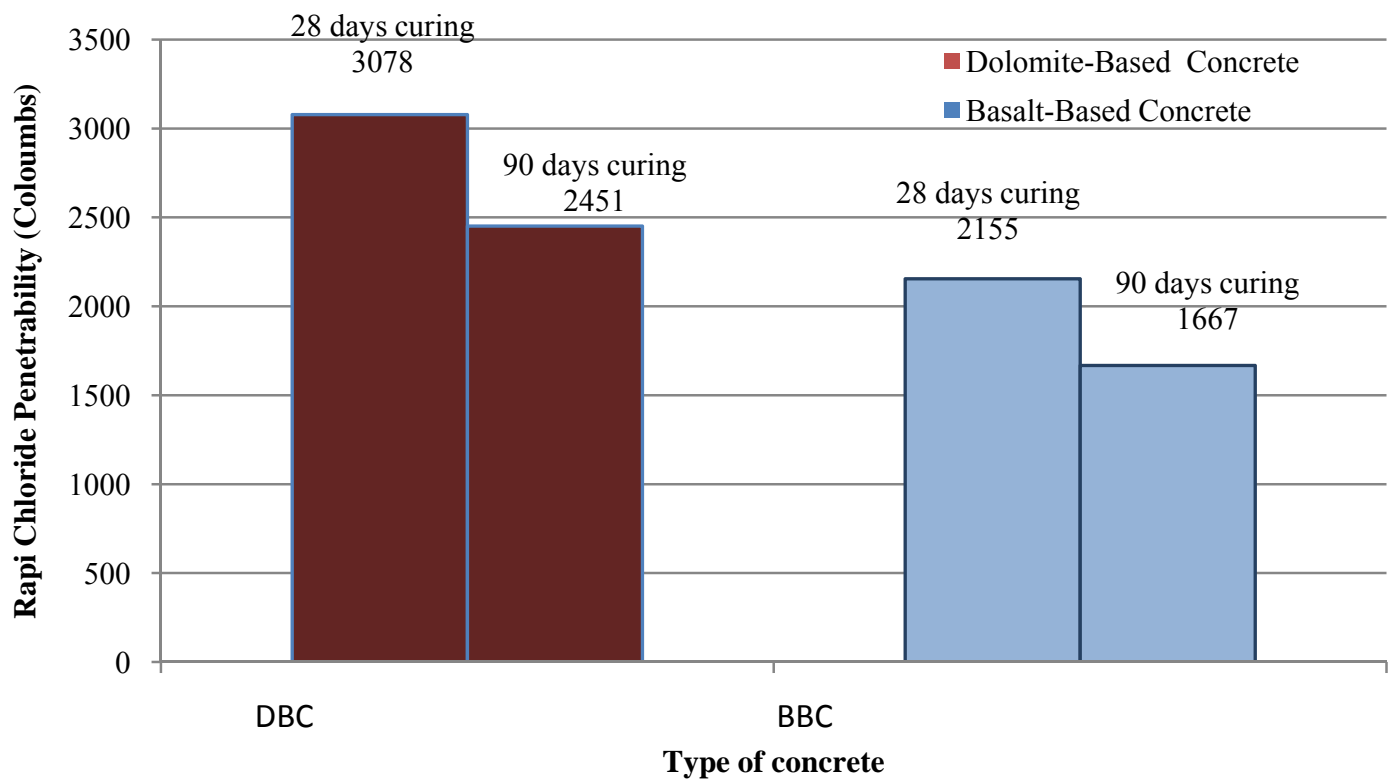

Fig. 20 Rapid Chloride Penetrability.

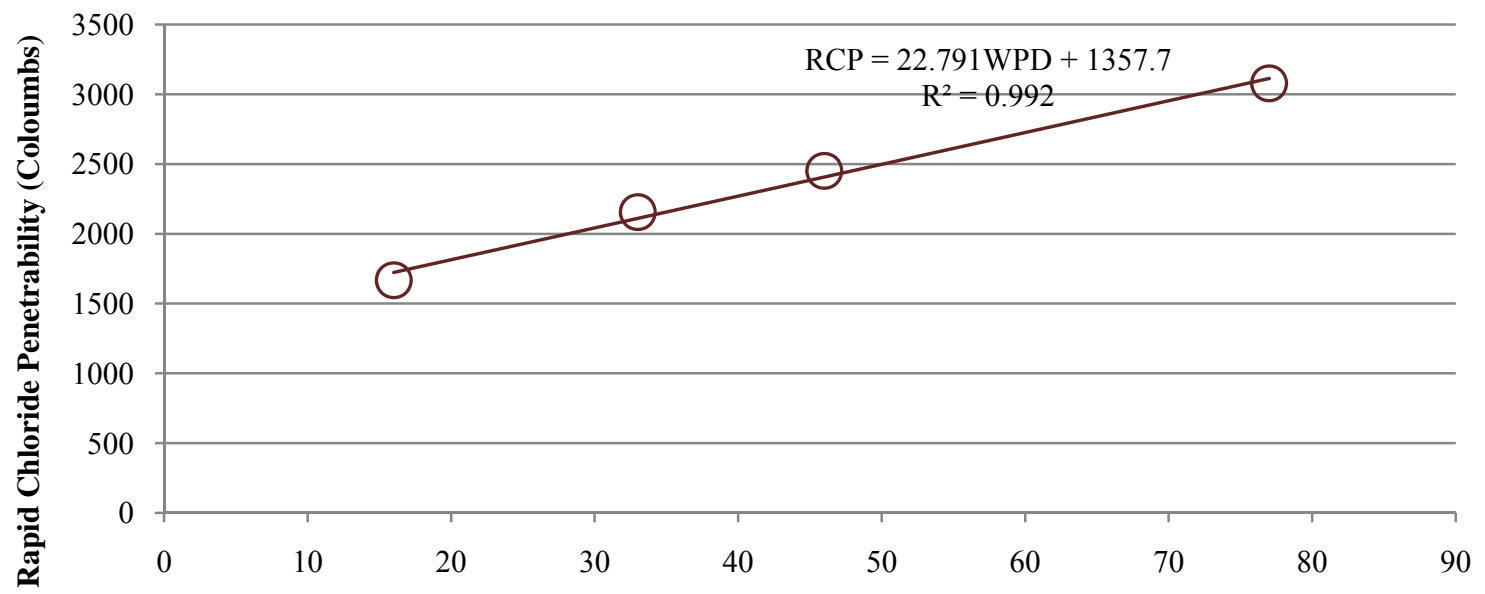

Water Penetration Depth (mm)

Fig. 21 Correlation between RCP and WPD.

However, this relationship should be investigated further with a wide range of aggregate types and w/c ratios.

\section{Conclusions}

Based on the experimental results reported in the paper, the following conclusions can be drawn:

Since the properties of As-Swaida'a basalt meet the specification limits, basalt can be used in the PC concrete mixes.

The physical and mechanical properties of crushed basalt aggregates were superior to those of crushed dolomite aggregates. However, the bulk specific gravity of the former was more than that of the latter aggregates. The unit weight of $\mathrm{BBC}$ was more than that of DBC. However, the increase in unit weight of BBC 
mix was approximately $1.4 \%$.

The specimens prepared with crushed basalt aggregates have lost more weight than the ones prepared with dolomite when exposed to $5 \%$ sulfuric acid solution. The weight losses of $\mathrm{BBC}$ specimens after 90 days of immersion were $50 \%$ more than DBC ones. Weight loss of $10 \%$ was obtained with BBC specimens at 15 days of exposure to $5 \% \mathrm{H}_{2} \mathrm{SO}_{4}$, but DBC specimens didn't achieve the same loss even after 90 days of immersion.

In hydrochloric, nitric and acetic acid solutions, acid protection of BBC specimens was better when compared to DBC ones. DBC specimens suffered more deterioration than $\mathrm{DBC}$ specimens by about a ratio ranging from 225 to $300 \%$.

Contrary to expectation, specimens of 90 days curing showed more deterioration than that of 28 days curing. This could be attributed to the increased levels of calcium hydroxide production in concrete after 90 days curing.

In deterioration of $\mathrm{BBC} \& \mathrm{DBC}$ in $5 \%$ sulfuric acid solution, the white surface of concrete exhibited the presence of gypsum and ettringite [38].

The better performance of concrete prepared with basalt aggregates indicate that this material can be beneficially utilized in the PC concrete exposed to all studied aggressive environments except $\mathrm{H}_{2} \mathrm{SO}_{4}$-containing environments.

There were good correlations between all kinds of attack on BBC specimens. This suggests that one attack data may be used to predict the concrete resistance to another kind of attacks and vice versa. However, this relationship should be investigated further with a wide range of aggregate types and $\mathrm{w} / \mathrm{c}$ ratios.

$\mathrm{BBC}$ specimens were found to be water impermeable after 28 and 90 days curing. Moreover, BBC specimens can be considered as water impermeable even under aggressive conditions.

The chloride penetrability of BBC specimens is lower than that of $\mathrm{DBC}$ specimens by approximately $20 \%$.

\section{Acknowledgement}

The authors gratefully acknowledge the technical and financial support of this research from the Order of Syrian Engineers. Thanks are also expressed to Prof. Tamer al-Hajeh for his help in some steps.

\section{References}

[1] Ibrahim, A., Faisal, S. and Jamil, N. 2009. "Use of Basalt in Asphalt Concrete Mixes." Construction and Building Materials 23 (1):498-506.

[2] Goodman, R. E. 1993. Engineering Geology: Rock in Engineering Construction. Wiley, New York.

[3] Tasong, W. S., Lynsdale, C. J. and Cripps, J. C. 1998. "Aggregate-Cement Paste Interface: II. Influence of Aggregate Physical Properties." Cement and Concrete Research 28 (10): 1453-65.

[4] Ozturan, T. and veCecen, C. 1997. "Effect of Coarse Aggregate Type on Mechanical Properties of Concretes with Different Strengths." Cement and Concrete Research 27 (2): 165-170.

[5] Ahmad, S. and Alghamdi, S. A. 2012. "A Study on Effect of Coarse Aggregate Type on Concrete Performance." Arab J Sci Eng. 37 (7): 1777-86.

[6] A Guide for mineral resources in Syria. 2011. The General Establishment of Geology and Mineral Resources in Syria (in Arabic).

[7] The General Establishemnt of Geology and Mineral Resources in Syria. 2007. Official document nr. (3207/T/9) (in Arabic).

[8] Swaida News. Accessed August 20, 2014. http://www.swaida.com. (in Arabic).

[9] Duchensne, J. and Bertron, A. 2013. "Leaching of Cementitious Materials by Pure Water and Strong Acids $\left(\mathrm{HCl}\right.$ and $\mathrm{HNO}_{3}$ )." In Alexander M., Bertron A., De Belie, Performance of cement-based materials in aggressive aqueous environments; state-of-the-Art Report, RILEM TC 211-PAE.

[10] Neville, A. M. 2011. Properties of concrete. Fifth edition. Pearson Education.

[11] Zivica, V. and Bajza, A. 2001. "Acid Attack of Cement Based Materials-A Review, Part1. Principle of acidic Attack." Construction and Building Materials 15: 331-40.

[12] Alexander, M. and Mindess, S. 2005. Aggregates in concrete. Taylor \& Francis.

[13] Fattuhi, N. I. and Hughes, B. P. 1988. "Ordinary Portland Cement Mixes with Selected Admixtures Subjected to Sulfuric Acid." ACI Materials Journal Nov.-Dec.:512-8.

[14] Skalny, J., Marchand, J. and Odler, I. 2002. Sulfate Attack on Concrete. Taylor \& Francis Group.

[15] Mehta, P. K. and Monteiro, P. J. M. 2006. Concrete: 
Microstructure, Properties, and Materials. $3^{\text {rd }}$ edition. McGraw-Hill.

[16] Dyer, T. 2014. Concrete Durability. Taylor \& Francis Group.

[17] ACI 201.2R-01. 2001. Guide to Durable Concrete. American Concrete Institute.

[18] Tamimi, A. K. 1997. "High-Performance Concrete Mix for an Optimum Protection in Acidic Conditions." Materials and Structures 30: 188-91.

[19] Kong, H. L. and Orbison, J. G. 1987. "Concrete Deterioration Due to Acid Precipitation." ACI materials Journal March-April: 110-6.

[20] Mindess, S., Young, J. F. and Darwin, D. 2003. Concrete. $2^{\text {nd }}$ Edition, Prentice Hall.

[21] Binda, C. and Baronio, G. 2006. "The Durability of Masonry in Aggressive Environments and Techniques for Its Conservation and Protection." In Yu, C. W. and Bull, J. W. Durability of Materials and Structures in Building and Civil Engineering. Taylor \& Francis group.

[22] Allahverdi, A. and Skvara, F. 2000. "Acidic Corrosion of Hydrated Cement Based Materials Part 1: Mechanism of the Phenomenon." Ceramics-Silicaty 44 (3): 114-20.

[23] Sand, W. 1997. "Microbial Mechanisms of Deterioration of Inorganic Substrates-A General Mechanistic Overview." International Biodeterioration \& Biodegradation 40 (2-4): $183-90$.

[24] Leemann, A. et al. 2010. "Influence of Water Hardness on Concrete Surface Deterioration Caused by Nitrifying Biofilms in Wastewater Treatment Plants." International Biodeterioration \& Biodegradation 64 (6): 489-98.

[25] Bertron, A. and Duchensne, J. 2013. "Attack of Cementitious Materials by Organic Acids in Agricultural and Agrofood Effluents." In Alexander, M., Bertron, A. and De Belie. Performance of cement-based materials in aggressive aqueous environments. state-of-the-Art Report, RILEM TC 211-PAE.

[26] The Aberdeen Group. 1957. Agencies that Attack Concrete. Publication nr. C571203.

[27] Maitre, L. et al. 1989. A Classification of Igneous Rocks and Glossary of Terms. Blackwell, oxford.

[28] Duriez, M. and Arrambide, J. 1962. Nouveau Traite de Materiaux de Constraction. Paris Dunod.

[29] Collepardi, M. 2006. The New Concrete. Grafiche Tintoretto first published.

[30] Kurdowski, W. 2014. Cement and Concrete Chemistry. Springer.

[31] Kosmatka, S. H. et al. 2009. Design and Control of Concrete Mixtures. Portland Cement Association.

[32] Attiogbe, E. K. and Rizkalla, S. H. 1988. "Response of Concrete to Sulfuric Acid Attack." ACI Materials Journal (Nov-Dec): 481-8.
[33] Monteny, J. E., Vincke, A., Beeldens, A., De Belie, N., Taerwe, L. and Van Gemert, D. 2000. "Chemical, Microbiological, and In Situ Test Methods for Biogenic Sulfuric Acid Corrosion of Concrete." Cement and Concrete Research 30 (4): 623-34.

[34] Monteny, J. E., De Belie, N., Vincke, E., Verstraete, W. and Taewe, L. 2001. "Chemical and Microbiological Tests to Simulate Sulfuric Acid Corrosion of Polymer-Modified Concrete." Cement and Concrete Research 31: 1359-65.

[35] Biczok, I. 1967. Concrete Corrosion and Concrete Protection, Chemical Publishing Co. Inc., New York.

[36] ACI 221R-2001: Guide for Use of normal Weight and Heavyweight Aggregates in Concrete. American Concrete Institute; 2001

[37] Hughes, B. P. and Guest, J. E. 1978. "Limestone and Siliceous Aggregate Concretes Subjected to Sulphuric Acid Attack." Magazine of Concrete Research 30 (102): 11-8.

[38] Hime, W. G. and Mather, B. 1999. "Sulfate Attack, or is It?" Cement and Concrete Research 29: 789-91.

[39] Pavlic, V. 1994. "Corrosion of Hardened Cement Paste by Acetic and Nitric Acids; Part I: Calculation of Corrosion Depth." Cement and Concrete Research 24: 551-62.

[40] Turkel, S., FelekOglu, B. and Dulluc, S. 2007. "Influence of Various Acids on the Physico-Mechanical Properties of Pozzolanic Cement mortars." Sadhana 32 (6): 683-91.

[41] Baron, J. and Ollivier, J. P. 1996. La Durabilité des Béton, Presses des Pont. Eyrolles, Paris.

[42] Pavlic, V. and Uncik, S. 1997. "The Rate of Corrosion of Hardened Cement Pastes and Mortars with Additive of Silica Fume in Acids." Cement and Concrete Research 27: 1731-45.

[43] Pavlic, V. 1994. "Corrosion of Hardened Cement Paste by Acetic and Nitric Acids; Part II: Formation and Chemical Composition of the Corrosion Products Layer. Cement and Concrete Research 24: 1495-508.

[44] Bensted, J. 1993. "Effect of Silage Upon Hardened Cement and Concrete." II Cemento 1: 3-10.

[45] Zivica, V. and Bajza, A. 2002. Acidic Attack of Cement-Based Materials-A Review Part 2. Factors of Rate of Acidic Attack and Protective Measures." Construction and Building Matreials 16: 215-22.

[46] Israel, D., Macphee, D. E. and Lachowski, E. E. 1997. "Acid Attack on Pore-Reduced Cement." J. Mater. Sci. 32 (15): 4109-16

[47] Elsharief, A., Cohen, M. D. and Olek, J. 2004. "Influence of Aggregate Type and Gradation on the Microstructure and Durability Properties of Portland Cement Mortar and Concrete." International RILEM Symposium on Concrete Science and Engineering. 